\title{
Santiago de Chile y Mendoza, Argentina: La red social que apoyó a exiliados chilenos (1973-1976)
}

\author{
Alejandro Paredes - Universidad Nacional de Cuyo - Centro de Estudios \\ Trasandinos y Latinoamericanos (CETyLA)-CONICET ${ }^{1}$
}

\section{Resumen}

El presente artículo describe las redes sociales que ayudaron a los exiliados chilenos que llegaron a la ciudad argentina de Mendoza luego del derrocamiento del Presidente socialista chileno Salvador Allende en 1973. Entre 1973 y 1989, la comunidad chilena exiliada en Mendoza fue grande. Este escrito se detiene en el periodo 1973-1976, porque en 1976 un golpe militar en Argentina cambió profundamente el escenario social del país, lo que justificaría que sea analizado en otro artículo. Las fuentes utilizadas son, principalmente, cartas que pertenecen al archivo del Comité Ecuménico de Acción Social, institución que apoyó a los chilenos que recibieron el estatus de Refugiados Políticos por el Alto Comisionados de las Naciones Unidas para los Refugiados (ACNUR).

Palabras clave: Redes Sociales, Exilio, Chile, Argentina.

\section{Abstract}

The present article describes the social networks that helped those exiled Chileans that arrived at the city Argentina of Mendoza after the overthrow of the socialist Chilean President Salvador Allende in 1973. Between 1973 and 1989, the Chilean community exiled in Mendoza was large. This writing stops in period 1973-1976, because in 1976 a military coup in Argentina deeply changed the social situation of the country, which would justify another article. The used sources are, mainly, letters that belong to the file of the Ecumenical Committee of Social Action, institution that supported the Chileans who received status of Political Refugees by High the Commissioners of the Nations United for Refugees (UNHCR).

Keywords: Social Networks, Exile, Chile, Argentina.

\section{Las relaciones de Mendoza con Santiago de Chile}

El Valle central de Chile y la provincia de Mendoza, en Argentina; ubicadas en las laderas de la cordillera de Los Andes, presentan ciertas identidades ${ }^{2}$ y complementariedades ${ }^{3}$. Mendoza es la cuarta ciudad más importante de Argentina y, por su cercanía con Santiago de Chile, el principal centro de comercio con ese país. La relación entre Mendoza y Santiago de Chile se comprende mejor al analizar el "Pacto Fundacional" de la ciudad de Mendoza. Según Bozzano (2000) el Pacto Fundacional opera en forma inconsciente en la dinámica social de una región determinada, ya que es un mandato implícito en la construcción de un territorio que

\footnotetext{
${ }^{1}$ Alejandro Paredes: aparedes@lab.cricyt.edu.ar

${ }^{2}$ La cuenca vitivinícola de esa región (la región del Maule en Chile y la Provincia de Mendoza conforman la más importante cuenca vitivinícola de América del Sur), el linaje común de las familias importantes a ambos lados de la cordillera y el origen colonial común, entre otros.

${ }^{3}$ Los procesos migratorios y la dinámica del exilio.
} 
sus pobladores transmiten de generación en generación ${ }^{4}$. No es casualidad que Mendoza se encuentre casi a la misma latitud que Santiago pero en la ladera oriental de la cordillera. Mendoza nació como un lugar de resguardo para los españoles de Santiago de Chile que no pudieron seguir hacia el sur del Bio-Bio. Los mapuches fueron el único pueblo no conquistado por los españoles. Su ingenio y firmeza obligaron a los hispanos a abortar las intenciones de llegar hasta el Estrecho de Magallanes y debieron retroceder hasta Santiago. De este modo decidieron enviar una expedición para fundar una ciudad del otro lado de Los Andes donde, según sabían, existía un pueblo agrario mucho más dócil que anteriormente había sido conquistado por los Incas $^{5}$. El objetivo de esta fundación era la constitución de un territorio donde pudiera pastar el ganado y cultivarse cereales para proveer a Santiago, cuya producción se veía asediada por los ataques mapuches. Así se fundó la ciudad con el nombre de Mendoza en honor a Pedro de Mendoza, quien entonces era el gobernador de Santiago, sucediendo a Pedro de Valdivia que había sido asesinado por los mapuches. Desde sus inicios esta ciudad fue pensada con relación a la capital chilena, como lugar de refugio de los santiaguinos, protegido por las montañas. La cercanía entre ambas ciudades, sus antecedentes de asilo para los exiliados (tanto chilenos en Mendoza como mendocinos en Santiago), el sistema montañoso que las separa y la pertenencia de distintos Estados Nacionales creó la sensación de resguardo frente a la persecución. Esta función, o en otras palabras, este Pacto Fundacional, fue reactualizado en las emigraciones de chilenos a Mendoza de 1814, 1970 y entre 1973-1989.

El artículo analiza la emigración de chilenos a Mendoza entre 1973 y 1976. El rescate de la red social formada por exiliados políticos chilenos y las organizaciones que los asistieron en Mendoza y en Santiago de Chile tuvo sus dificultades. La mayoría de los exilados abandonaron Mendoza y regresaron a Chile o reemigraron a otros países. Hacia 1980, por ejemplo, sólo el $25 \%$ de los refugiados políticos chilenos que llegaron a Mendoza en el segundo semestre de 1975 continuaba en el país ${ }^{6}$. La reconstrucción de esta red social en un periodo determinado, implicó dificultades en la frontera entre la historia y la sociología. Se apeló a la correspondencia de los refugiados chilenos y del Comité Ecuménico de Acción Social (que fue la institución que los acogió en Mendoza) y la realización de entrevistas a actores claves que aún residen en esa provincia argentina, utilizando el método de Bola de Nieve. Este estudio es parte de la investigación de tesis doctoral que toma

\footnotetext{
${ }^{4}$ Bozzano, Horacio (2000). Territorio reales, territorios pensados, territorios posibles, Bs. Aires: Espacio

${ }^{5}$ Fernández Rojas, Jorge (2003) "Felipe Esteve. El otro fundador de Mendoza”, Rumbos, N 14, Mendoza, 30/11/03, p.II

${ }^{6}$ Hojas HONVI del legajo 30-1178 al 30-1349, y del legajo 01-1324, archivo CEAS.
} 
al periodo 1973-1989, pero el presente artículo se detiene en el periodo comprendido entre el golpe militar chileno y el golpe militar en Argentina (19731976).

\section{La visualización de la red argentino-chilena}

Mendoza, a lo largo de su historia, vivenció la llegada de inmigrantes chilenos económicos y políticos. Entre los inmigrantes económicos se encontraron, por ejemplo, los que llegaron atraídos por la actividad minera mendocina en la década de 1840 y los que buscaron tierras de pastoreo hacia el sur. Entre los inmigrantes políticos pueden mencionarse los casi 3.000 patriotas chilenos que en 1814 debieron huir luego que la ciudad de Santiago fuera reconquistada por los realistas. El impacto fue enorme ya que la Aldea de Mendoza sólo tenía cerca de 5.000 pobladores y fueron recibidos por el General José de San Martín, con grandes honores ${ }^{7}$. Otro grupo numeroso de exiliados políticos llegó luego de la caída del Presidente socialista chileno Salvador Allende en 1973. Según el Censo Nacional Argentino de 1960, de los 825.535 habitantes de Mendoza, la comunidad chilena era sólo de 8.700 inmigrantes, es decir el 1,05 \% del total. En 1970 esta colectividad sólo representó al $0,85 \%$, cuando son censados 8.304 , sobre los 973.075 habitantes de la provincia. A partir de 1973, a raíz de la crisis política chilena que terminó en la ruptura violenta de su democracia; Mendoza, como ciudad de paso, volvió a centralizar la inmigración chilena que aumentó considerablemente, como se observa en el siguiente cuadro:

\footnotetext{
${ }^{7}$ Hudson, Damián (1931). Recuerdos históricos sobre la provincia de Cuyo, Mendoza: Editorial Revista mendocina de ciencias.
} 


\begin{tabular}{|c|c|c|}
\hline \multirow{2}{*}{ Gobierno } & \multicolumn{2}{|c|}{ Ingreso de inmigrantes chilenos a Mendoza } \\
\cline { 2 - 3 } chileno & Año & Cantidad \\
\cline { 2 - 3 } Unidad Popular & 1971 & 1.600 \\
& 1972 & 8.100 \\
& 1973 & 4.100 \\
\cline { 2 - 3 } & Total & 13.800 \\
\hline Gobierno militar & 1974 & 31.800 \\
(Primeros dos años) & Enero- Febrero de 1975 & 71.900 \\
\cline { 2 - 3 } & Total & 103.700 \\
\hline
\end{tabular}

Cuadro 1. Ingreso de migrantes chilenos a Mendoza (1971-1975)

Fuente: Heras, Guillot y Galvez, (1978). Migración Tradicional y Migración de Crisis. Una década de afluencias bolivianas y chilenas a Argentina y la región cuyana (1965-1975), Mendoza: PISPAL, p.13

No se ha encontrado, en la historia de ambos países, otra migración de un país limítrofe que la iguale en su masividad y en la velocidad con que se desarrolló. En 1974 la cantidad de ingresos casi se octuplicó con respecto al año anterior, pero sólo en los dos primeros meses de 1975 la cifra fue duplicada. Los 103.700 chilenos superaron a la cantidad de inmigrantes europeos que llegaron a Mendoza a fines del siglo XIX (100.240 en el censo de 1895); o a la población que en esos años tenía la Ciudad chilena de Talca (94.449 habitantes según el censo de 1970). A Fines de 1975 la Central Latinoamericana de trabajadores, basándose en datos proporcionados por sindicatos y organizaciones argentinas, calculaba que había cerca de 400.000 inmigrantes chilenos ilegales en el país rioplatense ${ }^{8}$. Según un estudio realizado por la Dirección de estadísticas y Censos de Mendoza, el 66\% de los chilenos que vivían en Mendoza en 1978, habían llegado después de $1973^{9}$.

Esta situación movilizó solidaridades que dieron origen a una red social que incluyó a organizaciones chilenas y argentinas. Para visualizar la red se utilizó el archivo del CEAS que está compuesto por un abundante epistolario y por una descripción de cada familia de refugiados identificados por números de legajos ${ }^{10}$. También se realizaron 24 entrevistas para ampliar lo obtenido en el archivo. El objetivo fue el de delimitar la red social que favoreció el exilio chileno en Mendoza a partir de los datos sobre las relaciones entre la comunidad exiliada en Mendoza y las organizaciones solidarias a ellas. Esto permitió describir la circulación de información y de los atributos principales de la relación y de sus nodos más

\footnotetext{
8 (s/f) “Un fenómeno angustiante", Bs As: CAREF, p.3, Bibliorato correspondencia enviada y recibida 1980, archivo CEAS.

${ }^{9}$ (1979) Anuario Estadístico 1977 y 1978, Mendoza: Dirección de Estadísticas y Censos, p.15

10 Para esto se tomaron 440 Cartas, 182 documentos de organizaciones, 16 declaraciones escritas de exiliados chilenos y los 2.539 legajos de familias de refugiados chilenos asistidos por el CEAS entre 1973 y 1989. El archivo del CEAS limita nuestro ámbito de estudio, dando lugar a una mayor prominencia de esta institución en la red social analizada. La fuente utilizada introduce un sesgo en términos de la centralidad atribuida al CEAS. No obstante, asumiendo dicha limitación, el archivo proporciona una información descriptiva de gran valor.
} 
importantes. Utilizando como criterio "se comunicaban entre sí" la red resultante fue la siguiente:

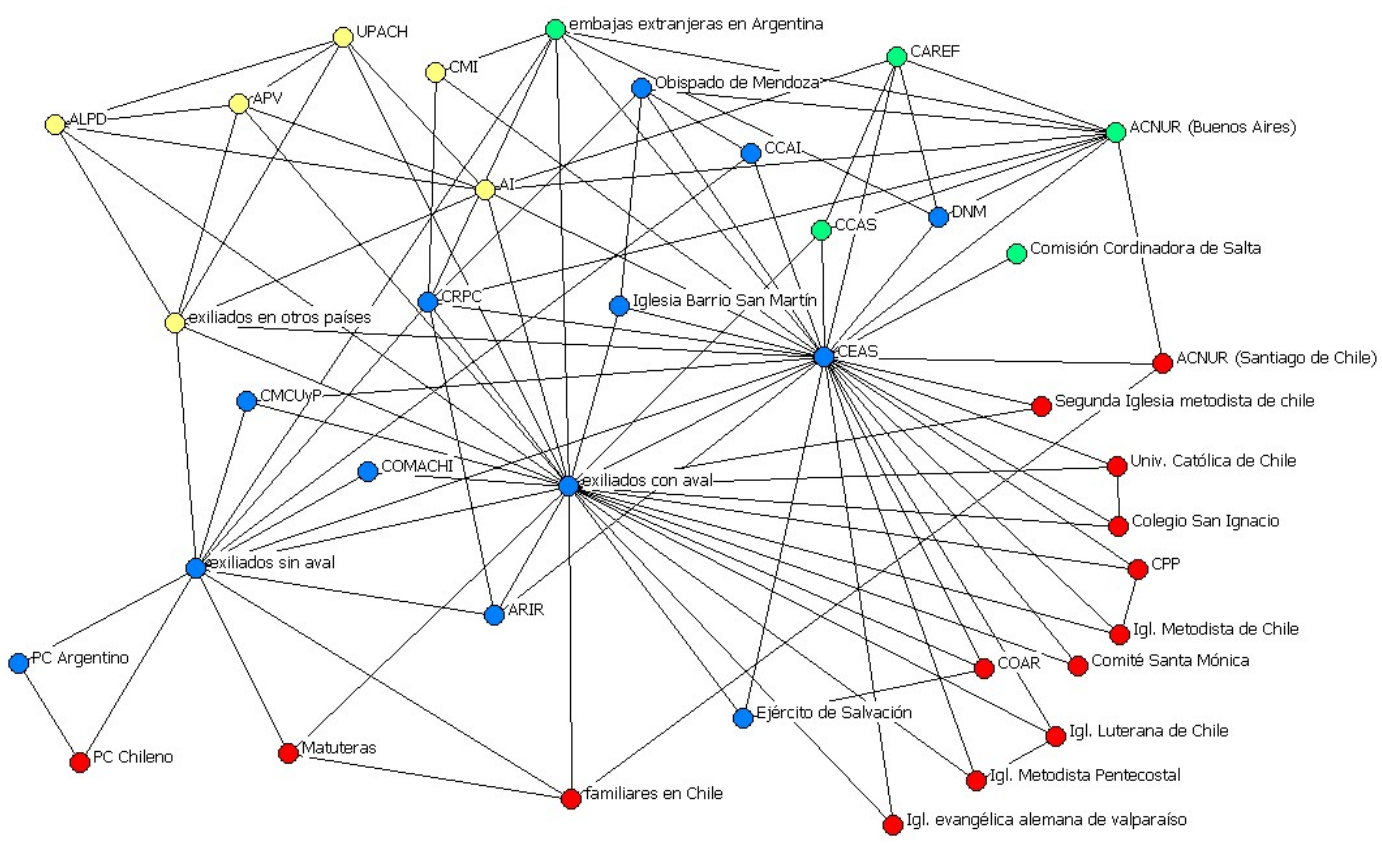

Figura 1. Red social en torno a los exiliados chilenos en Mendoza (1973-1976).

Fuente: Elaboración propia.

Color: En rojo nodos en Chile; en Azul nodos en Mendoza; en Verde nodos en otras provincias argentinas y en amarillo nodos en otros países.

Siglas: ACNUR Alto Comité de las Naciones Unidas para los Refugiados; Al Anmesty Internacional; ALPD Asociación Latinoamericana de Periodistas para el Desarrollo; APV Agrupación de Periodistas Venezolanos; ARIR Agrupación Refugiados de Izquierda Revolucionaria; CAREF Comisión de Apoyo al Refugiado; CCAI Comisión Católica Argentina para los Inmigrantes; CCAS Comisión Coordinadora de Acción Social; CEAS Comité Ecuménico de Acción social; CMCUYP Centro de Madres Chilenas Unidad y Progreso; CMI Consejo Mundial de Iglesias; COAR Comité de Ayuda al Refugiado; COMACHI Comité Argentino-Chileno; CPP Consejo para la Paz de Chile; CRPC Concejo de Refugiados Políticos Chilenos; DNM Dirección Nacional de Migraciones; PC Partido Comunista; UPACH Unión de Periodistas antifascistas Chilenos.

Se graficó en forma de red no direccionada ya que el criterio utilizado fue la existencia de una relación en ambos nodos. Eran relaciones recíprocas a partir del intercambio epistolar y de declaraciones escritas de refugiados (en el caso de los exiliados chilenos sin aval de alguna organización chilena). Es una red ubicada a nivel meso que relaciona a nodos locales y no locales ${ }^{11}$. Para su análisis, la comunidad de exiliados en mendoza fue tomada como una organización. Esto fue una opción metodológica a fin de comprender mejor las relaciones entre el gran número de exiliados (que eran 6.899 exiliados agrupados en 2.539 legajos del CEAS) y las organizaciones que los ayudaron. Debido a que, en cuanto al comportamiento relacional, se encontraron a dos grandes grupos de exiliados se los

\footnotetext{
${ }^{11}$ Ferrand, A. (2002) “Las comunidades locales como estructuras meso", Revista REDES. Vol.3, №4, http://revista-redes. rediris.es
} 
separó en dos nodos. Los que llegaron a Mendoza con algún aval de una institución chilena y los que no tuvieron ninguna o no lo quisieron mostrar. Esta decisión responde a que, como ha demostrado Narciso Pizarro, es posible definir una identidad individual (es decir nodal) como al conjunto de relaciones de pertenencia ${ }^{12}$. Esta definición de identidad es, como veremos más tarde, un concepto operativo que puede utilizarse como una potente herramienta en las ciencias sociales estructurales.

La red tiene una densidad es del 14,52 \% y está compuesta por 38 nodos distribuidos en Chile, Argentina y en otros países.

\begin{tabular}{|c|c|c|c|}
\hline Chile & Mendoza & Resto de Argentina & Otros países \\
\hline $\begin{array}{l}\text { ACNUR (Santiago) } \\
\text { COAR } \\
\text { Colegio San Ignacio } \\
\text { Comité Santa Mónica } \\
\text { CPP } \\
\text { Ejército de Salvación } \\
\text { Iglesia evangélica alemana de } \\
\text { Valparaíso } \\
\text { Iglesia Luterana de Chile } \\
\text { Iglesia Metodista de Chile } \\
\text { Iglesia Metodista Pentecostal } \\
\text { Matuteras } \\
\text { PC Chileno } \\
\text { Segunda Iglesia metodista de } \\
\text { chile } \\
\text { Univ. Católica de Chile }\end{array}$ & $\begin{array}{l}\text { ARIR } \\
\text { CCAI } \\
\text { CEAS } \\
\text { CMCUyP } \\
\text { COMACHI } \\
\text { CRPC } \\
\text { DNM } \\
\text { Exiliados con aval } \\
\text { Exiliados sin aval } \\
\text { Familiares en Chile } \\
\text { Igl. Barrio San } \\
\text { Martín } \\
\text { Obispado } \\
\text { PC Argentino }\end{array}$ & $\begin{array}{l}\text { ACNUR (Bs. As) } \\
\text { CAREF } \\
\text { CCAS } \\
\text { Comisión Coordinadora } \\
\text { de Salta } \\
\text { Embajadas extranjeras } \\
\text { en Argentina }\end{array}$ & $\begin{array}{l}\text { Al } \\
\text { ALPD } \\
\text { APV } \\
\text { CMI } \\
\text { Exiliados en } \\
\text { otros países } \\
\text { UPACH }\end{array}$ \\
\hline 14 nodos ( $37 \%$ ) & 13 nodos $(34 \%)$ & 5 nodos $(13 \%)$ & 6 nodos ( $16 \%)$ \\
\hline
\end{tabular}

Cuadro 2. Nodos según localización territorial.

Fuente: elaboración propia

El $71 \%$ de la red se distribuía en Mendoza y en la zona central chilena. Pero también incluía relaciones en el resto de Argentina y Chile y en otros países. Un caso especial eran las "matuteras" chilenas, que cruzaban la frontera periódicamente $^{13}$. Ellas compraban objetos en Argentina y los introducían clandestinamente para venderlos en Chile. Era un contrabando en baja escala (conocido también como "contrabando Hormiga") de mercancías de bajo valor, como cigarrillos y licores; que se vendían en las calles de Santiago. Esto era fomentado por la relación de cambio entre ambos países. Su actividad les permitió servir de puentes entre los exiliados y su familia, en un contexto en el que era

\footnotetext{
12 Pizarro, Narciso (2004) “Un nuevo enfoque sobre la equivalencia estructural: lugares y redes de lugares como herramientas para la teoría sociológica", REDES, Vol.5, №2, htpp://revista-redes.rediris.es

${ }^{13}$ Matutera deriva de la palabra matute (a escondidas, clandestinamente), en su mayoría eran mujeres.
} 
peligroso enviar cartas postales o usar el teléfono ${ }^{14}$. Si bien podría considerarse como un nodo con una bilocalización, se lo analizará como situado en Chile ya que era el lugar de residencia declarado por las matuteras.

Al profundizar el análisis de la red según el fin del intercambio entre los nodos, se puede encontrar que en realidad es una superposición de tres redes. Surge así una red de presentación de los exiliados chilenos en Mendoza; otra red que promovía el intercambio de recursos (principalmente económicos y de información) para brindar asistencia a estos exiliados y una tercera que favoreció la reemigración a otros lugares más seguros. Algunos nodos pertenecen a más de una red (el CEAS, por ejemplo participaba en las tres redes) mientras que otros eran miembros de una o dos de estas redes. El artículo continuará analizando a estas tres redes: La de presentación, la de asistencia y la de reemigración.

\section{La red de presentación}

La red de presentación de perseguidos políticos chilenos se reconstruyó a partir de la información de los legajos de los refugiados en los que figuraba si habían sido presentados por algún organismo. Muchos de los legajos incluían cartas de aval. Se hizo una lectura mínima de las mismas, de modo similar al trabajo de Plata Caviedes (2006) en la reconstrucción de las redes sociales de la FARC, ELN y las ACCU-AUC, es decir haciendo una lectura de la estructura gramatical básica SujetoVerbo- Objeto ${ }^{15}$. Se encontró que eran cartas breves con una presentación del portador de la carta y un agradecimiento de la ayuda que se le pudiera ofrecer. El Comité Para La Paz, por ejemplo, tenía las cartas escritas a máquina pero con líneas punteadas donde se completaba el nombre del exiliado.

\footnotetext{
${ }^{14}$ Entrevista realizada a miembro de la Comisión Chilena de Derechos Humanos, Santiago, enero 2002.

${ }^{15}$ Plata Caviedes leyó los comunicados de esas organizaciones limitándolos a su estructura gramatical básica (Sujeto- Verbo- Objeto), para codificarlos en base a las propiedades lingüísticas del texto. Plata Caviedes, Juan Camilo. "Reconstrucción de las redes sociales: el caso de las FARC, el ELN y las ACCUAUC", Revista Redes, Vol.10, Junio de 2006, p.4.
} 


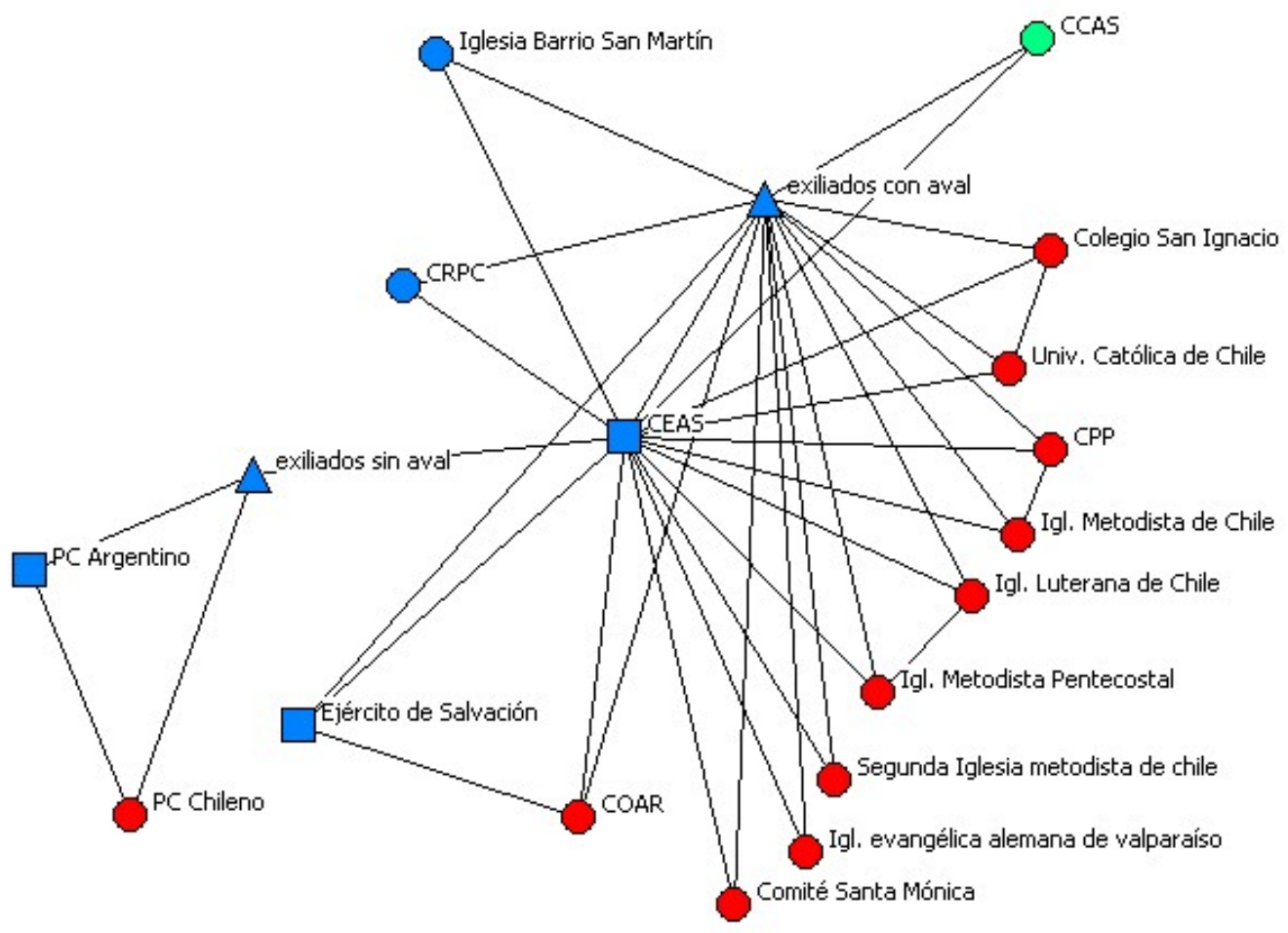

Figura 2. Red social de presentación de exiliados chilenos en Mendoza (1973-1976).

Fuente: Elaboración propia

Color: (según localización) nodos rojos en Chile; azul en Mendoza; verde en otras provincias argentinas

Formas: redondos nodos presentadores; Triángulos nodos presentados; cuadrados nodos receptores.

Siglas: CMI Consejo Mundial de Iglesias; CCAI Comisión Católica Argentina para los Inmigrantes; DNM Dirección Nacional de Migraciones; ARIR Agrupación Refugiados de Izquierda Revolucionaria; CRPC Concejo de Refugiados Políticos Chilenos; PC Partido Comunista; CMCUYP Centro de Madres Chilenas Unidad y Progreso; CEAS Comité Ecuménico de Acción social; COAR Comité de Ayuda al Refugiado; CPP Consejo para la Paz de Chile; CAREF Comisión de Apoyo al Refugiado; CCAS Comisión Coordinadora de Acción Social; ACNUR Alto Comité de las Naciones Unidas para los Refugiados.

La red aparece como una superposición de tríadas de roles: nodos presentadores, nodos presentados y nodos receptores, que reciben la presentación. Tomando como mínimo la participación de 3 nodos en la formación de una camarilla, 11 cliques fueron encontrados. 


\begin{tabular}{|c|c|c|c|}
\hline Cliques & Presentado & Presentador & Receptor \\
\hline 1. & exiliados con aval & $\begin{array}{c}\text { CPP } \\
\text { Igl. Metodista de Chile }\end{array}$ & CEAS \\
\hline 2. & exiliados con aval & $\begin{array}{c}\text { Igl. Luterana de Chile } \\
\text { Igl. Metodista Pentecostal }\end{array}$ & Ejército de Salvación CEAS \\
\hline 3. & exiliados con aval & COAR & CEAS \\
\hline 4. & exiliados con aval & Comité Santa Mónica & CEAS \\
\hline 5. & exiliados con aval & $\begin{array}{c}\text { Segunda Iglesia Metodista de } \\
\text { Chile }\end{array}$ & CEAS \\
\hline 6. & exiliados con aval & $\begin{array}{c}\text { Igl. Evangélica Alemana de } \\
\text { Valparaíso }\end{array}$ & CEAS \\
\hline 7. & exiliados con aval & $\begin{array}{c}\text { Univ. Católica de Chile } \\
\text { Colegio San Ignacio }\end{array}$ & CEAS \\
\hline 8. & exiliados con aval & CRPC & CEAS \\
\hline 9. & exiliados con aval & CCAS & PC Argentino \\
\hline 10. & exiliados con aval & Iglesia Barrio San Martín & PC Chileno \\
\hline 11. & exiliados sin aval & C & CEAS \\
\hline
\end{tabular}

Cuadro 3. Cliques de la red de Presentación, según roles de presentación y localización

Colores: En rojo nodos en Chile; en Azul nodos en Mendoza; en Verde nodos en otras provincias argentinas.

Fuente: elaboración propia.

Tanto en la figura № 2 como en el cuadro № 3 predominan los nodos rojos (11 nodos) y azules ( 7 nodos), evidenciando la naturaleza trasandina de la red, en la que organizaciones chilenas presentaban a los perseguidos chilenos ante sus pares mendocinos. Sólo dos organizaciones en Mendoza avalaron la condición de perseguido político de chilenos ante el CEAS, uno era el Concejo de Refugiados Políticos Chilenos (clique № 8), y otro era el Padre José María Llorens (clique № 10), sacerdote jesuita muy cercano al grupo ecuménico que había creado al CEAS. El número nueve se refiere a chilenos que habían sido aceptados como refugiados políticos por el CCAS en Buenos Aires y que luego se mudaron a Mendoza. Las camarillas formadas por cuatro nodos se refieren a exiliados que trajeron más de una carta de aval (1, 2 y 7) y a otros (el № 3) que eran presentados ante el Ejército de Salvación (una organización cristiana) que a su vez los presentaba ante el CEAS.

Los cliques muestran once circuitos distintos de presentación de perseguidos políticos chilenos ante organizaciones mendocinas. En ellos el CEAS es el gran receptor (10 de los once circuitos) y los exiliados con aval eran los más contenidos en su llegada. Los que no tenían aval y pertenecían al Partido Comunista chileno fueron alojados por sus miembros del Partido Comunista Argentino, algunos no pidieron ayuda al CEAS y otros sí. Los que no pertenecían al Partido Comunista Chileno ni tenían cartas de aval se presentaron directamente ante el CEAS explicando su situación de perseguidos. A veces fueron aceptados y otras veces no. 
Los dos apartados que siguen a continuación se centran en aspectos de la red de presentación de los exiliados políticos chilenos. El apartado que sigue se detiene en los exiliados sin aval que no fueron asistidos por el CEAS y en la impronta trasandina de la red. El apartado 3.2 se detiene en la materialización de la red en las cartas de presentación.

\subsection{El cruce constante de la cordillera de los exiliados chilenos}

Una característica de los exiliados que no adquirieron el estatus de ACNUR con respecto a los que sí lo hicieron, fue que los primeros retornaron a Chile con mayor frecuencia. Los refugiados políticos avalados por ACNUR a través del CEAS no podían volver a su país, de hacerlo perdían el estatus y por lo tanto, toda ayuda económica. Muchos exiliados no refugiados retornaron a Chile antes de la redemocratización de ese país y, en caso de ser perseguidos nuevamente, volvían a exiliarse. Otros regresaron por razones comerciales. Se quedaban en Mendoza pocos días para comprar cosas a bajo costo y venderlas en Santiago. A este oficio, se lo conocía en Chile como el trabajo de las "matuteras" y fue masivo durante la década del setenta gracias a la relación de cambio de las monedas argentina y chilena ${ }^{16}$. Pero si bien tenían mayor libertad para regresar que los refugiados, en contrapartida, se encontraban menos protegidos ante la persecución. En Mendoza, una residente del Barrio Cristo Salvador (un barrio construido por inmigrantes chilenos durante la dictadura en Argentina, cuyo nombre "Salvador" hacía alusión a Salvador Allende) recordaba:

Cualquier chileno que [...] estaba ilegal, lo corrían, lo sacaban de las casas, de las villas, o de las residenciales y los ponían de patitas en los autobuses ${ }^{17}$.

Dos refugiados denunciaron ante el CEAS que en 1976 que unos exiliados chilenos habían sido detenidos en la puerta de su casa por una patrulla militar. Pero el comité no pudo hacer nada porque no gozaban del estatus de refugiados políticos de ACNUR.

"Ahora estos compañeros están en Chile en distintos campos de concentración", se quejaba un refugiado ${ }^{18}$.

Lionel, un miembro del partido comunista, fue detenido en Chile por personal de la DINA y rescatado por un sargento, que había sido compañero colegio, cuando iba a ser llevado a Puen Ala, un campo de concentración. El militar lo llevó hasta su casa

\footnotetext{
${ }^{16}$ Entrevista realizada a miembro de la Comisión Chilena de Derechos Humanos, Santiago, enero 2002.

17 Sra. Violeta (primer presidente de la Unión Vecinal Cristo Salvador), desgrabación de la primera cinta de focus group, 13/3/85, por las Asistentes Sociales de la Fundación Ecuménica de Cuyo, p.4, en Carpeta Cristo Salvador, archivo CEAS, Mendoza

${ }^{18}$ Carta del refugiado a ACNUR, 21/1/77, p.1, legajo 30-759, archivo CEAS.
} 
y le aconsejó que saliera de Chile. En Mendoza vivía de trabajos pagados al día y alquilaba una habitación con miembros del ERP (grupo guerrillero argentino de los años setenta) aunque no militaba en el movimiento.

Cuando este grupo cayó detenido [declaró el exiliado] me llevaron a mí también. Luego de torturarme durante tres días, me tiraron a un descampado famoso por ser depósito de heridos y cadáveres, que es Papagayo. Tenía los ojos vendados y las manos amarradas a la espalda. Después de este hecho decidí volver a Chile en octubre de 1976. Llegué a mi casa en Chillán [en Chile]. A los pocos días fui detectado. Personal de civil, me detuvo en mi casa. Fui interrogado sobre mi estadía en Argentina y actividades anteriores. Me dejaron en libertad pero me ordenaron que no me moviera de mi casa ya que en cualquier momento podían venir a buscarme. Después de evaluar mi situación decidí volver a Argentina ${ }^{19}$.

Feliciano fue miembro de la Juventud Comunista de Viña del Mar desde los 13 años, en 1972 ya era miembro del Partido Comunista Chileno. Luego del golpe militar fue despedido y sus compañeros presos le indicaron que él figuraba en la lista de los próximos a detener. En febrero de 1974 llegó a la Argentina. En 1977 volvió a Viña del Mar y fue designado dirigente regional del Partido Comunista en esa ciudad. En 1984 fueron detenidos varios compañeros. Como se enteró que era vigilado regresó a Mendoza. En 1989 pidió ayuda a ACNUR para regresar ${ }^{20}$.

Luis llegó a Argentina el 5 de enero de 1976 y obtuvo el estatus de refugiado político. En 1978 se fue con su familia a Francia. En diciembre de 1986 volvió a Chile y se alojó en una casa de un amigo. A los ocho días, el 4 de enero de 1987, cuatro personas de civil que se identificaron como del $\mathrm{CNI}$ registraron la casa; robaron casi todas las cosas que habían traído de Francia; le pegaron a una de las hijas y los amenazaron a ellos y a los dueños de casa por comunistas. El 10 de enero huyeron a Mendoza y vivieron sin el estatus de refugiado político hasta 1989 fecha en que pidieron ayuda a ACNUR para volver a Chile ${ }^{21}$.

Domingo fue sacado por la fuerza de la empresa Ralco, en la que trabajaba y fue encarcelado por tres años y dos meses. El dos de noviembre de 1976 se acogió al decreto N504 que permitía la conmutación de la pena por la de extrañamiento. Ese mismo día partió a Francia con su esposa y tres hijos. En julio de 1979, se separó de su esposa y decidió volver a Chile allí estuvo hasta el 4 de abril de 1985, cuando huyó de los servicios de inteligencia que lo habían detectado y se exilió en

\footnotetext{
${ }^{19}$ Declaración del exiliado en "Solicitud de Ayuda al ACNUR", 21/11/91, en Carpeta Repatriaciones 1991, archivo CEAS, Mendoza.

20 Declaración del exiliado en "Solicitud de Ayuda al ACNUR", 16/11/89, en Carpeta Repatriaciones (8889), Letra GH, archivo CEAS, Mendoza

${ }^{21}$ Declaración del exiliado en "Solicitud de Ayuda al ACNUR", 14/8/89, en Carpeta Repatriaciones (8889), Letra KL, archivo CEAS, Mendoza
} 
Mendoza. Durante los casi seis años de estadía en su país desarrolló diversas actividades comerciales de compra y venta en las ferias libres para atender su sustento diario. En Mendoza se dedicó a la construcción y formó pareja, teniendo dos hijos. En 1991 regresó a Chile con su familia y se establecieron con parientes en Puerto Mont ${ }^{22}$.

Elisa era una enfermera que no militaba políticamente, pero al ser testigo de la represión el miedo la retrajo, por lo que comenzó a ser observada con desconfianza por sus superiores.

En varias oportunidades en que me toco trabajar en el turno de la noche, tuve que soportar el interrogatorio de la CNI [Comisión Nacional de Inteligencia]. Ellos irrumpían en la dependencia de enfermería sembrando el terror. Amenazaban, interrogaban. En una ocasión, me tuvieron paralizada con una metralleta apuntándome a la cabeza. Pude comprobar como se llevaban enfermeras jóvenes, según decían era para interrogarlas. Se decía que las torturaban y violaban, pero ellas callaban y nunca denunciaron estos hechos. Toda esta situación me aterrorizaba. Cuando los veía llegar disparaba por los pasillos para esconderme. Eso los enfurecía porque decían que algo tendría yo que esconder para proceder así. Como no podían probarme nada, sólo renovaban las amenazas. En Agosto de 1975, fui citada por la enfermera Jefe, quien luego de someterme a un interrogatorio sobre supuestas actividades políticas, me quería obligar a firmar un papel donde reconocía una militancia comunista. Me negué a ello y me obligó a firmar mi renuncia ${ }^{23}$.

En 1975, ingresó por primera vez a Argentina pero no consiguió estabilidad laboral y regresó a Chile. Durante tres años peregrinó entre Mendoza y Santiago. Algunos meses en Chile vendía artesanías y algunos meses en Mendoza, cuidaba ancianos. En 1978 comenzó a trabajar como enfermera en el Servicio Nacional de Menores de Chile. Pero en 1981, la repartición fue asumida por carabineros y ella fue exonerada por decreto. Así no pudo trabajar en ningún otro lado y se estableció en Mendoza hasta 1991, cuando la democracia volvió a Chile ${ }^{24}$.

\subsection{La red mendocino-santiaguina que favoreció el cruce de la frontera}

Muchos chilenos cruzaron la cordillera de Los Andes a pie. Desde antaño, aborígenes y misioneros cristianos cruzaron la cordillera a pie o a lomo de mula ${ }^{25}$. Posteriormente a fines del siglo XIX y principios del siglo XX, contingentes de campesinos chilenos cruzaron con su ganado y prácticamente poblaron la Patagonia

\footnotetext{
22 "Solicitud de Ayuda ACNUR", 25/11/91, en Carpeta Repatriaciones 1991, archivo CEAS, Mendoza.

23 Declaración de la exiliada en "Solicitud de Ayuda ACNUR", 31/10/91, en Carpeta Repatriaciones 1991, archivo CEAS, Mendoza

24 “Solicitud de Ayuda ACNUR", 31/10/91, en Carpeta Repatriaciones 1991, archivo CEAS, Mendoza

${ }^{25}$ Maza, Juan (1991). Malargüe, Mendoza: Editorial de la Fac. de Filosofía y Letras- Universidad Nacional de Cuyo, p.33
} 
Argentina ${ }^{26}$. Como el ejército chileno efectuó un control intenso de los pasos cordilleranos, los militantes socialistas buscaron alternativas para cruzar la cordillera caminando. El control se intensificó más aún cuando la inteligencia chilena alertó al ejército chileno que miembros del Movimiento de Izquierda Revolucionario (MIR), intentaban cruzar la cordillera a pie. En San Juan (provincia argentina al norte de Mendoza), el Paso de Los Patos vio ingresar clandestinamente, a fines de 1973, a un militante del Partido Socialista de 34 años, ex presidente de los Consejos Regionales de Mineros y ex presidente de la Comisión Nacional del $\mathrm{Oro}^{27}$. En Neuquén (provincia argentina al sur de Mendoza) otro exiliado de 26 años hizo lo mismo y luego viajó a Mendoza para presentarse ante el CEAS, en $1975^{28}$. También baqueanos de Malargüe, departamento de Mendoza, aseguraron que varias personas llegaron a Argentina desde Chile, con ayuda de los puesteros; utilizando el Paso el Yeso, ubicado a 2.600 metros de altura sobre el nivel del mar. Por este último paso, llegaron a la Argentina miembros del Partido Socialista de la ciudad de Talca ${ }^{29}$. Esta situación causó que en 1978 Gendarmería Nacional y Migraciones prohibieran, transitoriamente, el cruce de arrieros chilenos a Argentina por los pasos de Santa Elena y Vergara, en Mendoza ${ }^{30}$. Según una militante chilena, otros llegaron utilizando las vías del tren trasandino. A determinada altura de la cordillera, un grupo subía a un vagón de carga en desuso y era empujado por otros ${ }^{31}$.

Otro dato que define la relación de la inmigración con la crisis política chilena es que el 31,4\% ingresó a la Argentina en el segundo semestre de 1974 (el 23,1\% entre Agosto y Octubre), de este total el 70,8\% ingresó por vía terrestre, sin embargo, casi una cuarta parte lo hizo por vía aérea $(24 \%)^{32}$. Esto se debió a que muchos pudieron llegar a Mendoza gracias a la red de organizaciones chilenas que financiaron los pasajes aéreos de los casos más urgentes y acordaron, con otras organizaciones argentinas, la recepción del inmigrante en el aeropuerto. En

\footnotetext{
${ }^{26}$ Carrasco Norambuena, Carmen. “La chilenización de Neuquen” En: Araucanías y pampas. Un mundo fronterizo en América del Sur, ediciones Univ. De la frontera, pp.212-238.

27 Declaración del refugiado (manuscrito, sin fecha), carpeta "Repatriaciones voluntarias (1988-1989)", letra M. Archivo CEAS, Mendoza.

${ }^{28}$ Legajo 30-0814, archivo CEAS.

${ }^{29}$ Bustelo, Gastón (2001). “Impacto de la dictadura pinochetista en Mendoza (1973-1988)”, Revista de Estudios Trasandinos №5, Santiago de Chile, pp.355-356. Para una profundización de la cultura de frontera argentinochilena ver: Codina, Iverna (1993), Detrás del Grito, Mendoza: Ediciones Culturales Mendoza.

30 Scher, Ofelia B. (1997). “Inmigración limítrofe a la República Argentina una aproximación al caso chileno 1950/1990" Revista de Estudios Trasandinos, №1, pp.211 y 219

${ }^{31}$ Entrevista realizada a miembro de la Comisión Chilena de Derechos Humanos, Santiago, enero 2002

${ }^{32}$ Heras, E; Guillot, D. y Galvez, R. Op. Cit. pp.133-135
} 
Mendoza, el Comité Ecuménico de Acción Social monopolizó la ayuda aunque el partido comunista argentino en Mendoza hizo lo propio ayudando a sus pares chilenos. En general el recién llegado traía también una carta de presentación de la organización que lo enviaba y muchas veces otra carta con información confidencial para ambas organizaciones ${ }^{33}$. El Comité Ecuménico confirmaba telefónicamente si todo había salido bien, cuidando sus palabras con frases como: "Muchas gracias, recibí el regalito o bien, llegaron los dos paquetes, gracias por los regalos"34.

El gráfico anterior de la red de presentación no muestra frecuencias. En general en la visualización de las redes esto se suple con el grosor o el color de los lazos o de los nodos que se quieren resaltar ${ }^{35}$. Sin embargo, aún no es tan exacto como las tablas que muestran frecuencias. En contraposición al panorama holístico y relacional de las redes, las tablas sirven para detenerse en las individualidades y en los atributos de los elementos que la conforman. Su complementariedad enriquece los análisis. Con este fin se tomaron los primeros 378 casos que fueron asistidos por el CEAS. De ellos el $74 \%$ de los que se tiene información, traían una carta de presentación de alguna institución chilena. El cuadro también muestra el medio de transporte por el que llegaron los exiliados ${ }^{36}$.

\begin{tabular}{|c|c|c|c|c|c|c|c|c|c|c|c|c|c|c|}
\hline \multirow{2}{*}{$\begin{array}{l}\text { I nstitución } \\
\text { Transporte }\end{array}$} & \multicolumn{3}{|c|}{$\begin{array}{c}\text { Comité } \\
\text { para la Paz }\end{array}$} & \multirow{2}{*}{$\begin{array}{c}\text { Comité } \\
\text { Sta. } \\
\text { Mónica } \\
\text { a) }\end{array}$} & \multicolumn{3}{|c|}{$\begin{array}{c}\text { Igl. } \\
\text { Luterana de } \\
\text { Chile }\end{array}$} & \multirow{2}{*}{$\begin{array}{c}\text { Metodista } \\
\text { Pentecost } \\
\text { al } \\
\text { a) }\end{array}$} & \multicolumn{4}{|c|}{$\begin{array}{l}\text { Sin aval de } \\
\text { Institución }\end{array}$} & \multirow{2}{*}{$\begin{array}{c}\begin{array}{c}\text { Sin } \\
\text { datos }\end{array} \\
\text { d) }\end{array}$} & \multirow[t]{3}{*}{ Total } \\
\hline & a) & b) & d) & & a) & b) & d) & & a) & b) & c) & d) & & \\
\hline $\mathrm{N}^{\circ}$ Casos & 182 & 3 & 6 & 1 & 6 & 5 & 2 & 2 & 28 & 32 & 3 & 10 & 100 & \\
\hline $\mathrm{N}^{\circ}$ pers. & \multicolumn{3}{|c|}{227} & 1 & \multicolumn{3}{|c|}{21} & 6 & \multicolumn{4}{|c|}{119} & $\mathrm{~S} / \mathrm{d}$ & 368 \\
\hline Total casos & \multicolumn{3}{|c|}{191} & 1 & \multicolumn{3}{|c|}{13} & 2 & \multicolumn{4}{|c|}{73} & 100 & $378^{37}$ \\
\hline$\%$ & \multicolumn{3}{|c|}{50,30} & 0,25 & \multicolumn{3}{|c|}{3,45} & 0,50 & \multicolumn{4}{|c|}{19,20} & 26,30 & 100 \\
\hline
\end{tabular}

Cuadro 4. Cartas de aval de los primeros 378 exiliados asistidos por CEAS.

Leyenda: Medio de transporte por el que ingresaron a Mendoza: a) aéreo, b) ómnibus, c) ferrocarril trasandino, d) sin datos

Fuente: Datos de los legajos N³0-0001 al 30-0378, archivo CEAS, Mendoza

Los refugiados que aparecen en el cuadro anterior llegaron a Mendoza entre fines de 1973 y 1975. En su mayoría, los exiliados que traían cartas habían tenido que dejar a sus familias en Chile. Los 205 casos con cartas del cuadro anterior, representaron a 249 personas, es decir a una carta cada 1,20 exiliados. Por lo

33 En el archivo del CEAS puede encontrarse distintos legajos con cartas de presentación de estas instituciones en las que afirman que han pagado el viaje hasta Mendoza.

${ }^{34}$ Entrevista a la Dra Juana Juri, asesora legal del CEAS 03/03/05, Mendoza.

35 Molina, José L. (2001). El análisis de redes sociales. Una introducción. Barcelona: Edicions Bellaterra. Apartado "El problema de la visualización" pp.98-100.

${ }^{36}$ Un aporte interesante son los estudios de las redes sociales retomados por la geografía del transporte a las que aplica los conceptos de flujos y transportación. El concepto de Flujo se refiere al intercambio de mercancías y personas de un aérea a otra y el de transportación a la vía concreta y conocida por la que se realiza el intercambio (Potrykowski, Marek y Taylor, Zbigniew (1984). Geografía del transporte. Barcelona: Ariel, pp.12-13).

${ }^{37}$ Sólo se sumaron una vez los legajos 30-0191 y 30-0348 que tenían 2 cartas de presentación cada una 
general, la llegada de los familiares a Mendoza se producía meses después, cuando comenzaban a ser hostigados para obtener la dirección del exiliado. De los 191 casos que tenían una carta del Comité para la Paz, sólo 17 vinieron con sus familias $^{38}$ y un exiliado ingresó con parte de la familia ${ }^{39}$. El $80 \%$ de los portadores de las cartas del Comité para la Paz tenían entre 17 y 31 años.

Las organizaciones chilenas que financiaron los pasajes y presentaron al exiliado ante el CEAS fueron, principalmente el Comité para la Paz de Chile, la Iglesia Luterana de Chile y la Comisión de Ayuda al Refugiado (COAR) ${ }^{40}$. En menor medida también colaboraron la I glesia Metodista Pentecostal, la Iglesia Evangélica Alemana de Valparaíso ${ }^{41}$, La Iglesia Metodista de Chile y la Segunda Iglesia Metodista ${ }^{42}$. El COAR, desde Santiago envió una carta que pedía asistencia a 19 exiliados políticos, es decir a 19 familias $^{43}$. Un refugiado llegó con una carta de recomendación del Colegio San Ignacio, donde había sido alumno y de la Universidad Católica de Chile, donde trabajó ${ }^{44}$. Sólo en dos casos, la presentación la realizó una organización mendocina, era una carta del padre Llorens del barrio San Martín ${ }^{45}$; y en un caso la carta de presentación la escribió otro refugiado miembro del Concejo de Refugiados Políticos ${ }^{46}$.

Estas organizaciones también fueron perseguidas en su país. El Comité para la Paz, fue disuelto por el gobierno a fines de 1976. Violeta trabajaba para el Comité de Santa Mónica junto a sacerdotes y religiosas. A fines de 1975 su domicilio fue allanado y su hijo de 14 años fue detenido e interrogado. Ella también fue

\footnotetext{
38 Legajos: 30-0065; 30-0108; 30-0131; 30-0256; 30-0309; 30-0314; 30-0315; 30-0316; 30-0326; 30-0333; 30-0337; 30-0340; 30-0341; 30-0342; 30-0359; 30-0362 y 30-0371. Archivo CEAS.

39 Legajo 30-0133, archivo CEAS, Mendoza.

${ }^{40}$ Carta de la COAR al CEAS, 3/2/75, legajos 30-0828 y 30-0829. Archivo CEAS. Ambas cartas tenían la misma fecha y los dos refugiados viajaron sin sus familias, vía terrestre.

${ }^{41}$ Carta de la Iglesia Evangélica Alemana de Valparaíso al CEAS, 3/1/75 y 26/2/75, leg. 30-0768, archivo CEAS. Allí pide se ayude a una familia de seis personas.

42 Carta de la Segunda I glesia Metodista al CEAS, 9/1/75, leg. 30-0804, archivo CEAS. Presenta a una familia de 3 personas que llegaron a Mendoza vía terrestre, para reunirse con dos hijos que ya estaban en Argentina.

${ }^{43}$ Carta del COAR al Ejército de Salvación en Mendoza, Santiago, agosto de 1975, leg. 30-1186. archivo CEAS, Mendoza.

${ }^{44}$ Carta de presentación Universidad Católica de Chile, S/F y carta de presentación Colegio San Ignacio, 10/12/74, legajo 30-779. Archivo CEAS, Mendoza.

${ }^{45}$ Carta de José María Llorens al Comité Ecuménico, Barrio San Martín, 4/11/75, Legajos 30-1275 y 30 1273. archivo CEAS

46 Carta de presentación del refugiado 30-704, al que luego será el refugiado 30-1244, Mendoza, 10/10/75. En ella explica que el recién llegado se encuentra resentido física y psíquicamente debido a que "recorrió un buen número de campos de concentración". También traía un certificado firmado por el coronel Jorge Espinoza Ulloa que afirmaba que estuvo preso entre el 5/10/73 y el 10/11/74 en el Estadio Nacional, Chacabuco, Punchuncavi y Tres Álamos sin haberse comprobado que hubiere contravenido normas constitucionales, santiago, 18/6/75. Ambos documentos en: Legajo 30-1244, archivo CEAS.
} 
interrogada y debido a los fuertes golpes recibidos quedo completamente sorda. Violeta había sido operada de un oído varios años antes y conservaba algo de audición. Después de días de interrogatorios, quedaron bajo arresto domiciliario con vigilancia permanente. Finalmente toda la familia se exilió en Mendoza ${ }^{47}$. Mucho más tardíamente, a principios de mayo de 1986, comenzó un proceso denominado “Proceso a la Vicaría" que detuvo a 24 miembros de esa organización ${ }^{48}$.

\section{La Red de Asistencia}

Otra red se conformó en torno a la asistencia de los exiliados que llegaron a Mendoza. La red de presentación estaba compuesta casi totalmente por nodos rojos ( situados en Chile) y azules (situados en Mendoza). En un sólo caso un nodo era de otro color (el CCAS, de Buenos Aires), ya que era la dimensión de la red que posibilitaba el cruce de la frontera argentino-chilena. En la Red Social de Asistencia el Predominio azul era absoluto: Once nodos azules frente a tres rojos, dos amarillos y uno verde. Esto implicó que la Red de Asistencia comprometió más a los nodos que se encontraban en Mendoza. Aunque tampoco puede olvidarse que los dos nodos amarillos representaban el 33\% del acceso de la red al escenario internacional. El gráfico direccionado ilustra la relación "A ayuda a B".

47 Informe social CCAl, marzo de 1980, Letra A, Carpeta Informe social, archivo CEAS, Mendoza.

48 (1987) "Refugiados de América del Sur", Refugees-Refugies-Flüchtlinge-Refugiados, N86, Geneva: World Council of Churches, p.3 


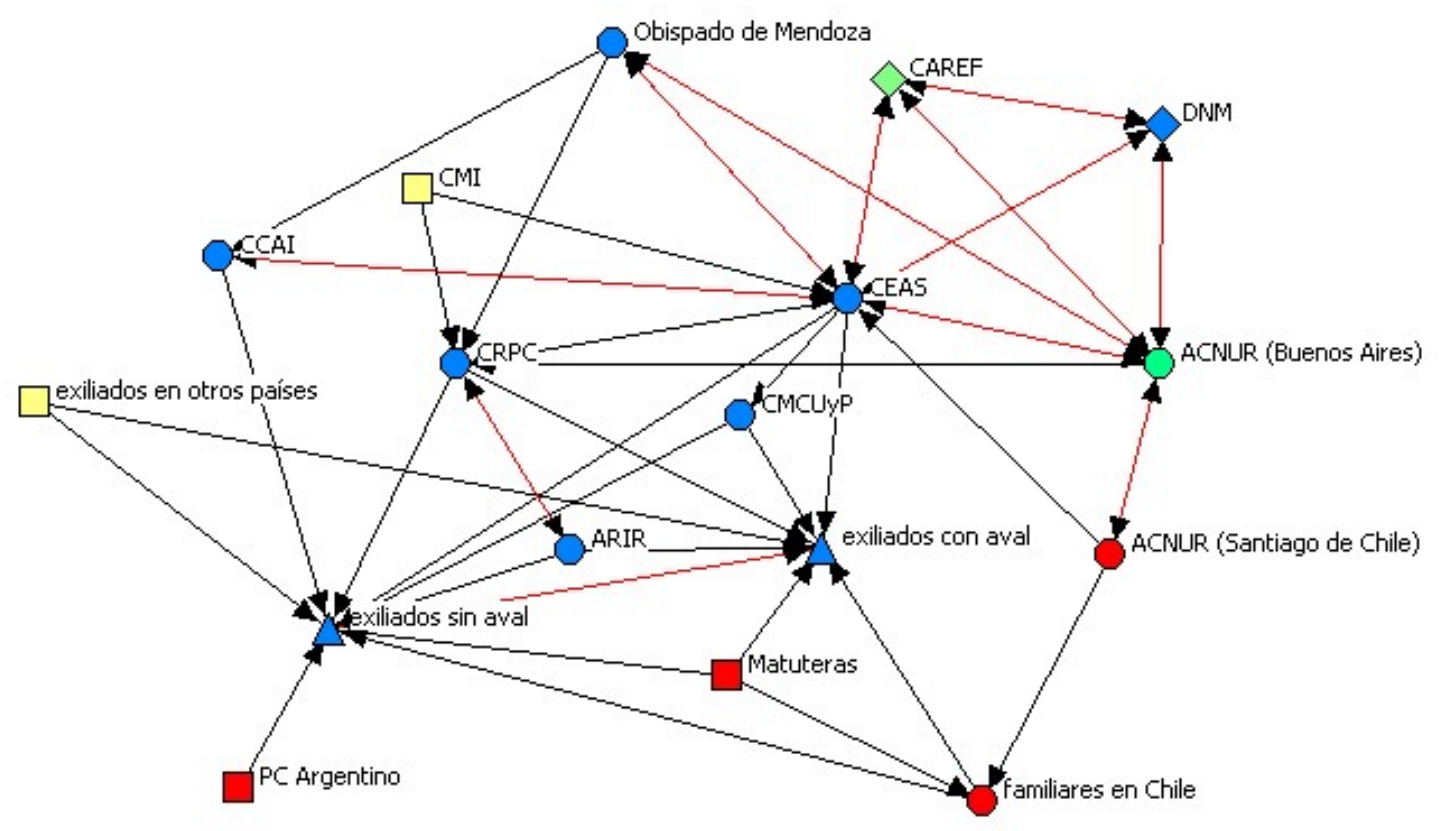

Figura 3. Red social de asistencia a exiliados chilenos en Mendoza (1973-1976).

Formas de los nodos: Cuadrados sólo ayudan; rombos sólo relaciones recíprocas, círculos ayudan y reciben ayuda de nodos distintos; triángulos casi no brindan ayuda.

Color de los nodos: En rojo nodos en Chile; en Azul nodos en Mendoza; en Verde nodos en otras provincias argentinas y en amarillo nodos en otros países.

Color de los lazos: En rojo relación de ayuda recíproca y en negro relación no recíproca de ayuda.

Siglas: CMI Consejo Mundial de Iglesias; CCAI Comisión Católica Argentina para los Inmigrantes; DNM Dirección Nacional de Migraciones; ARIR Agrupación Refugiados de Izquierda Revolucionaria; CRPC Concejo de Refugiados Políticos Chilenos; PC Partido Comunista; CMCUYP Centro de Madres Chilenas Unidad y Progreso; CEAS Comité Ecuménico de Acción social; CAREF Comisión de Apoyo al Refugiado; ACNUR Alto Comité de las Naciones Unidas para los Refugiados.

Fuente: Elaboración propia.

En la red aparecen comportamientos diferentes. Se encuentran nodos-fuentes que sólo entablaron relaciones de ayuda hacia otros miembros de la red (el Consejo Mundial de Iglesias, los exiliados en otros países, el Partido Comunista Argentino y las matuteras). Los refugiados chilenos en Mendoza (los con aval y los sin aval), si son vistos como una unidad, son un agujero estructural de la Red. Analizándolos por separado no lo son porque tienen entre ellos una relación de colaboración mutua (dos o más familias alquilaban una casa para abaratar costos, los esposos buscaban trabajos juntos, escribían cartas conjuntas pidiendo ayuda a alguna organización, etc.). Esta relación fortaleció también la salud mental de los exiliados liberándolos de estrés y bajando los niveles de impotencia como será analizado en el apartado 4.2. 
El agujero estructural conformado por ambos justificaba la existencia de la Red de Asistencia, ya que el objetivo de la misma era asistirlos. Esto explica también que los nodos que sólo entablaron relaciones de colaboración recíproca tenían que estar a una distancia de más de dos lazos de los exiliados chilenos con o sin aval. (CAREF y Dirección Nacional de Migraciones). Finalmente más de la mitad de los nodos de la red entabló relaciones en la que recibió y dio asistencia a nodos diferentes: El Obispado de Mendoza, la Comisión Católica Argentina para los Inmigrantes, los familiares en Chile, el CEAS, el Concejo de Refugiados Políticos Chilenos, el Centro de Madres Chilenas Unidad y Progreso, ACNUR (Buenos Aires), ACNUR (Santiago de Chile) y la Agrupación Refugiados de Izquierda Revolucionaria.

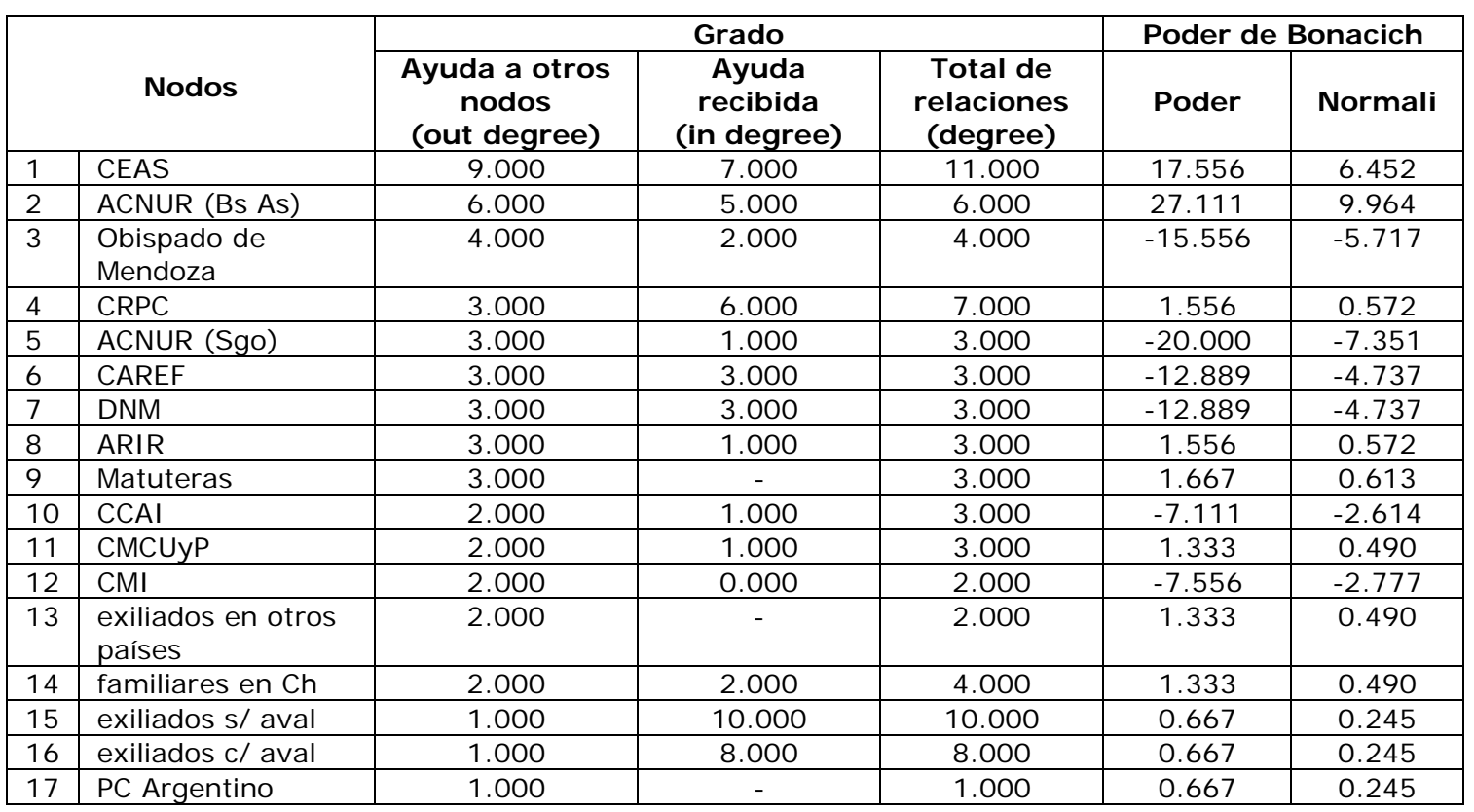

Cuadro 5. Grado e Indicador de Poder de Bonacich de la Red de Asistencia.

Fuente: Elaboración en base a datos procesados por Ucinet 6 Copyright (c) 1999-2005 Analytic Technologies

En el Cuadro 6, el Grado mide el nivel de solidaridad de cada uno de los nodos. Los nodos con un mayor grado de salida (outdegree) eran los que ayudaron a una mayor cantidad de nodos de la red. Por el contrario, los que recibieron muestra de solidaridad de más nodos, ostentan un mayor grado de entrada (indegree). El cuadro anterior demuestra que los que mayor solidaridad recibían de la red (es decir los que tenían un mayor grado de entrada) eran los que tenían menos poder en la misma. La Red de Asistencia estaba centralizada en un 46,25\% y el CEAS tenía el degree más alto. Era la organización que a más nodos de la red ayudaba y la solidaridad que recibía de su entorno era casi tan alta como la de los mismos exiliados chilenos. Otro aspecto a analizar es el grado de poder de los nodos. En él se ve que los menos poderosos de la red son los exiliados, que son vulnerables a las decisiones de sus benefactores. Los valores del indicador de Poder de Bonacich 
de los nodos 4 , 8 y 11, muestran también que los intentos de los exiliados de organizarse para tener más poder en el interior de la red fueron en vano. Sin embargo, son los más beneficiados por la red que se construyó entorno a ellos. En la red de asistencia ayudar daba poder, porque se generaba relaciones de dependencia con otros nodos. El próximo apartado se detendrá en el CEAS, que nació en Mendoza para ayudar a los exiliados chilenos. Posteriormente se analizará otro aspecto interesante de la Red de Asistencia: Los beneficios que significó para la salud mental de los exiliados chilenos en Mendoza participar en relaciones de colaboración mutua con sus pares.

\subsection{El nacimiento del Comité Ecuménico Acción Social (CEAS)}

En Mendoza, partidos políticos, asociaciones sindicales, religiosas y diferentes organizaciones establecieron estrategias para ayudar a los inmigrantes chilenos, pero la que más persistió (aún después de 1976, cuando un golpe militar sacudió a la Argentina) fue el movimiento ecuménico. A principios de diciembre de 1973, este grupo ecuménico pasó de atender de dos o tres familias nuevas por día a veinte o treinta y se comunicó con el Comité por la Paz en Chile de Santiago y de otras ciudades trasandinas. Ante la dificultad de atender cada vez a más personas, en marzo de 1974 decidieron convocar a todas las iglesias para considerar la magnitud del problema y crear una comisión que los asista. Así el 20 de marzo de 1974 nació, luego de algunas semanas de discusión, el Comité Ecuménico de Acción Social, CEAS. El mismo estaba conformado por la Iglesia Luterana, la Iglesia Católica Apostólica Romana (a través de un representante oficial del arzobispo de Mendoza Monseñor Olimpo Santiago Maresma), la Iglesia Evangélica del Río de la Plata y Iglesia Evangélica Metodista Argentina. También colaboraron Cáritas Argentina, la Cruz Roja Argentina y la Comisión Católica Argentina de Inmigración. En ese mes, la delegación para Latinoamérica del Alto Comisionado para las Naciones Unidas para los Refugiados (ACNUR) visitó a todas las organizaciones similares de la Argentina. Allí el CEAS consiguió el aval de ACNUR, para conseguir las garantías legales del refugiado y, junto a la colaboración del Consejo Mundial de Iglesias, dinero para asistirlos.

El ceas comenzó a funcionar en el edificio del Templo Metodista, en el centro de Mendoza. Cada salón se convirtió en oficinas atestadas de papeles, no había sanitarios necesarios para las cientos de personas que cada día llegaban al comité, ni lugares cómodos para el grupo de trabajo ${ }^{49}$. El Comité Ecuménico tomaba cada

49 Cf. "Ecumenical teamwork in Mendoza Argentina", p.9, manuscrito en inglés escrito el 2/5/77 por Alieda Verhoeven, Coordinadora General del CEAS, para su posible publicación en la revista Migration Today. Carpeta Correspondencia año 1977, Archivo CEAS, Mendoza. 
pedido de asistencia de los exiliados chilenos, los evaluaba y otorgaba o no el estatus de refugiado político asistido por ACNUR. Hacia 1977, asistía cerca de 2.000 personas ${ }^{50}$. Esa fue la mayor cantidad de refugiados simultáneos que atendió el Comité. En total, durante toda su existencia, desde 1973 a 1992, el CEAS dio refugio a 2.539 casos. Cada caso podía ser individual o incluir a un grupo familiar por lo que abarcó a 6.899 personas que fueron asistidas por el comité.

El CEAS también denunció casos de desapariciones en Chile. Teresa y su esposo, fueron refugiados en Mendoza por el CEAS y posteriormente viajaron a Suecia desde allí intentaron por todos los medios encontrar a su hermana y su cuñado que habían desaparecido de su hogar el 10 de julio de 1974. Ambos eran militantes del MIR. Aunque ellos creían que se encontraban en el campo de concentración de la Academia de la Fuerza Aérea Chilena en Santiago, nadie les daba respuesta. Antes de salir de Chile, el Comité de Santa Mónica había presentado un recurso de amparo pero fue rechazado. El mismo día que el CEAS se enteró de la situación, pidió el esclarecimiento de los hechos ante organismos chilenos y argentinos ${ }^{51}$. Esta actitud comprometida del Comité Ecuménico, le costó ser incluido entre los grupos perseguidos por los aparatos represivos de la dictadura argentina entre 1976 y 1983, que incluyó la explosión de dos bombas en sus oficinas, persecución de sus miembros y la desaparición de uno de ellos.

\subsection{La relación de colaboración mutua entre los exiliados chilenos en Mendoza y el impacto positivo en la salud mental.}

El destierro fue una experiencia muy dura para los exiliados. En algunas cartas quedaron plasmadas sus angustias:

Que no digan que hay gentes aquí y en otros lugares de América peor que la situación de un refugiado político, el cual ha sido desarraigado de su Patria y habiendo sido objeto de todo tipo de atropello, torturas, persecuciones ${ }^{52}$.

El 30 de agosto de 1979, en una conferencia de prensa del Comité de Familiares Exiliados informó que hasta esa fecha había 30 casos de suicidios entre los exiliados ${ }^{53}$.

50 Carta del CEAS una familia refugiada en Nueva Zelanda, Mendoza, 22/1/77. Bibliorato Correspondencia 1977, Letra A, Archivo CEAS, Mendoza

51 Carta del refugiado al CEAS, 24/1/75; Memorandum elevado a Frank Krenz (ACNUR) por el CEAS, 24/1/75 y Carta de la Coordinadora de Acción Social (ccas) al CEAS, 24/2/75. En: Leg 30-362, archivo CEAS.

52 Carta del refugiado al CEAS, Mendoza 21/11/78 legajo 30-780, archivo CEAS

53 Orellana, Patricio (1981) El exilio chileno. Falmer: Institute of Development Studies-University of Sussex, p.73 
En Mendoza, la imposibilidad de incorporarse en el mercado laboral los hizo ocupar un rol de marginalidad que muchos no tenían en Chile. Esto fue válido tanto para los que adquirieron el estatus de refugiado político como para los que no. Los que no tuvieron el estatus de refugiado político, usaron como estrategia las idas y venidas a Chile, buscando trabajo o comerciando en ambos lados de la cordillera de Los Andes. Esto les generó gran una inestabilidad económica y familiar. Muchos de ellos eran migrantes económicos desplazados por las medidas económicas chilenas de reducción estatal y las medidas argentinas de obstaculizar a los extranjeros el ingreso al mercado laboral formal. A los que huían por cuestiones políticas se le sumó el estrés de ser perseguidos en ambos países. Los psicólogos del CEAS atendieron a numerosos casos de trastornos causados por el exilio.

Para los refugiados, mantenerse en la Red de Asistencia que ayudaba a nuevos exiliados chilenos bajaba su sentimiento de impotencia. Ya que en la mayoría de los casos la migración implica "la ruptura de la red social de pertenencia"54.

Cuando nos trasladamos a Argentina - dice una carta enviada a todas las embajadas en Argentina por el consejo de Delegados de Refugiados Políticos de Mendoza - concientemente sabíamos que estábamos tomando una de las decisiones más difíciles en la vida de un ser humano: desarraigarse, marcharse por ver nuestras vidas y las de nuestras familias en peligro de muerte ${ }^{55}$.

En las relaciones de colaboración mutua, ellos sentían que estaban haciendo algo por contrarrestar la situación. Además fortalecía su identidad grupal en una situación adversa y servía de contención para los recién llegados, disminuyendo el estrés y la ansiedad. Un caso modelo fue el de una mujer de 25 años que figura con el nombre de " $A$ " y era una militante universitaria que debió salir clandestinamente de Chile por un pedido de detención librado por el gobierno militar. Llegó a Mendoza y solicitó refugio político. Al tiempo formó pareja con un argentino, pero nunca quiso casarse porque pensaba regresar a Chile. Se sentía rechazada en Mendoza y extrañaba a su familia y a su país. Según declaraba, era militante de izquierda desde niña y provenía de una familia de políticos de la Unidad Popular. Asistió a un psicólogo del CEAS debido a una sensación de angustia, ahogo, dolores de cabeza y episodios depresivos frecuentes. Entendía que volver a Chile era un riesgo grave pero insistía en la posibilidad de retornar. Su terapeuta le señaló que retornar es confrontarse con el peligro de morir. Aquí, empezó a articular en su

54 Dabas, Elina Dora (1998). Red de redes. Las prácticas de la intervención en redes sociales. Buenos Aires: Paidós (2a reimpresión), capítulo 7: “Construyendo territorios. Migración, marginalidad y organización social", p.164

55 Carta del Consejo de Delegados de Refugiados Políticos en Mendoza a todas las embajadas en Argentina, 27/8/78, Bibliorato Correspondencia 1978: Letra D, archivo CEAS. 
historia la necesidad de confrontarse con el máximo peligro y salir viva. Comprendió lo arrogante de cumplir tareas peligrosas a pesar de su miedo y la idea de retornar a Chile aunque su situación legal no lo permitiera sin riesgos graves. Empezó a discriminar entre su opción por una militancia política concreta y algo que va más allá, como el desafío de estar casi en riesgo de muerte. De ese modo, conectada aquí con grupos de chilenos politizados, comenzó a plantear su participación en actividades que, para ella, no significaron un retorno a ese desafío tan peligroso. Sus síntomas disminuyeron y sus episodios depresivos se redujeron. Finalmente, terminó el tratamiento ya que se sentía mejor ${ }^{56}$.

Esto muestra claramente como el alto impacto negativo del exilo en el equilibrio mental, pudo ser revertido por la inclusión de la refugiada en prácticas políticas propias de solidaridad con los chilenos en Mendoza. La culpa de haber dejado la lucha había dejado huellas muy profundas y le impedía rearmar su vida en Mendoza (por ejemplo, la imposibilidad de optar por construir una pareja con un argentino), esto fue revertido al retomar la militancia política. Los efectos positivos a nivel individual (pudiendo ser estos: Contención en Mendoza, fortalecimiento de la identidad grupal e individual, disminución de sentimientos nocivos como impotencia, derrota y culpa y reforzamiento ideológico) incentivaron la permanencia en la lucha en torno a la situación chilena desde Mendoza.

\section{La Red de Reemigración}

Muchos de los que llegaron a Mendoza continuaron siendo perseguidos por los que debían partir hacia otro lugar. Esta situación generó otra red cuyo fin fue ayudar a los refugiados a atravesar los obstáculos (principalmente legales aunque también económicos), que les impedía salir del país. En la red de reemigración participaron la totalidad de los nodos que no estaban ni Argentina, ni en Chile. Ante el inminente golpe militar en Argentina, el pánico se apropió de la comunidad chilena en Mendoza.

¿Qué pasaría con nosotros? ¿Seríamos devueltos a Chile? ¿Se nos tomaría prisionero? ¿Se nos mataría? ¿Se nos enviaría a otro país? ¿Qué haría la ONU en este caso? ${ }^{57}$

Preguntaban en una carta 12 familias jóvenes y una pareja mayor sin hijos menores de edad. Era el temor de 47 chilenos, de los cuales 23 eran niños. Frente

56 "Rehabilitación psicosocial de refugiados en Argentina. Caso Srta A", 4/4/86, Cartas Notas enviadas del año 1982 a 1987; archivo CEAS.

57 Carta de doce familias de refugiados chilenos en Mendoza al Presidente de la Comisión de Derechos Humanos de la ONU, S/F, Mendoza, Legajos 30-0835; 30-0896; 30-0915; 30-0949; 30-0952; 30-1016; 30-1321; 30-1341; 30-1364; 30-1377; 30-1388; 30-1397 Bibliorato Correspondencia 1976, archivo CEAS. 
a esto, la mayoría de los exiliados chilenos comenzaron a movilizar estrategias para salir del país y esta red se fortaleció, favoreciendo un desplazamiento en cadena para disminuir los costos de la nueva emigración ${ }^{58}$. En muchos casos la reemigración a terceros países separaba a familias que habían permanecido juntas en Mendoza. Dos hermanos, Diego y José María, llegaron a Mendoza el 21 de febrero de 1975, pero uno partió a Suecia y el segundo a Australia ${ }^{59}$. Además, si la mayoría llegó a Mendoza con las pocas pertenencias que pudieron cargar, al trasladarse a otros países debieron devolverle al CEAS lo que le había prestado. Los terrenos y casas comprados con dinero del CEAS también eran devueltos para que pudiera ser utilizado por otro compatriota. En este contexto, participar de una red que ayudase a los chilenos que recién llegaban era un modo de no sufrir tanto el exilio. Contar con una red de contención en el nuevo país de asilo era importante para aquellos que tuvieron una militancia mayor y reforzaron otras identidades grupales además de la nacionalidad, como la de pertenencia a determinado partido o gremio. Muchos buscaron destinos con ideologías políticas afines, como países de Europa del Este, por ejemplo. Otros buscaron destino donde las prácticas de denuncia a los atropellos del gobierno militar de Chile, fueron importantes.

58 Sobre las redes de desplazamientos internacionales puede leerse: Maya Jariego, Isidro (2004). “La formación de comunidades de inmigrantes: desplazamiento en cadena y contexto de recepción", Revista Araucaria. Año 5, № 12, http://www.institucional.us.es/araucaria

59 Legajos 30-0828 y 30-0829. Archivo CEAS, Mendoza. 


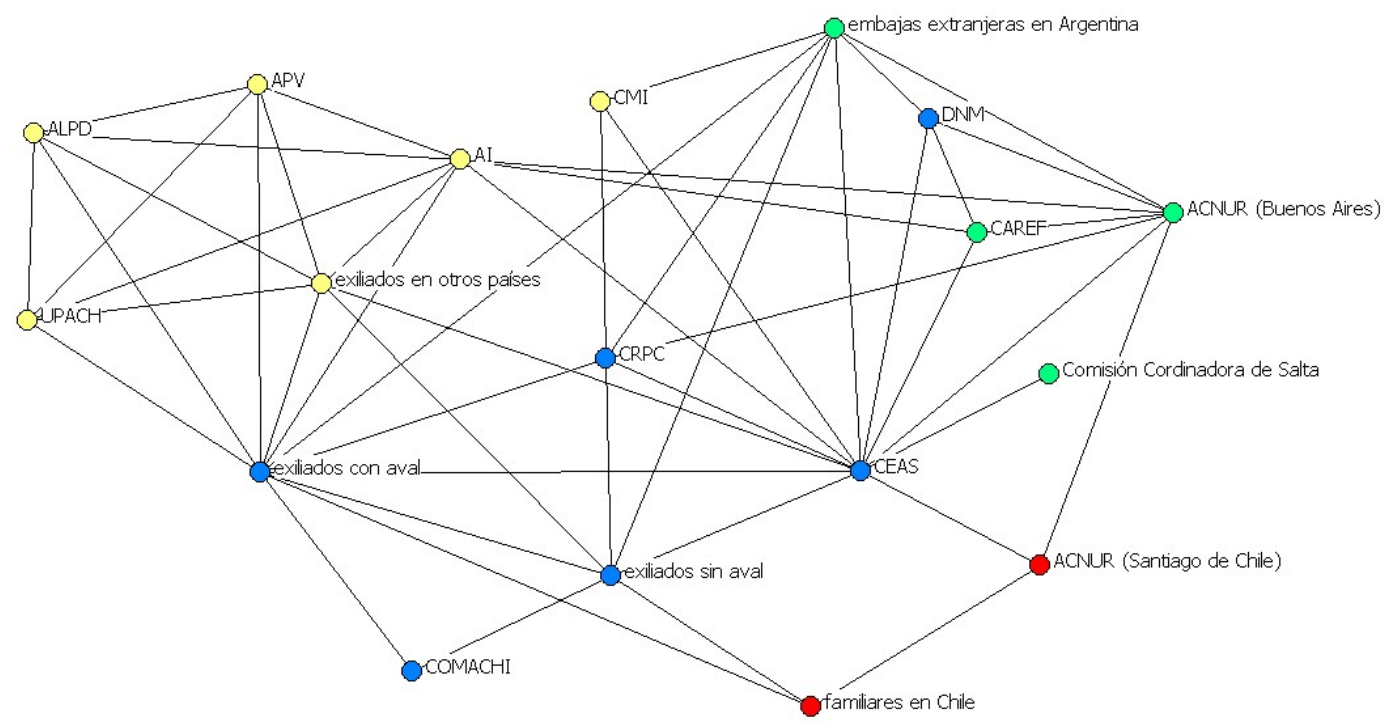

Figura 4. Red social de reemigración de exiliados chilenos en Mendoza (1973-1976)

Fuente: Elaboración propia

Color: En rojo nodos en Chile; en Azul nodos en Mendoza; en Verde nodos en otras provincias argentinas y en amarillo nodos en otros países.

Siglas: CRPC Concejo de Refugiados Políticos Chilenos; CEAS Comité Ecuménico de Acción social; COMACHI Comité Argentino-Chileno; ACNUR Alto Comisionado de las Naciones Unidas para los refugiados; CAREF Comisión de Apoyo al Refugiado; CMI Consejo Mundial de Iglesias; UPACH Unión de Periodistas antifascistas Chilenos; Al Anmesty Internacional; APV Agrupación de Periodistas Venezolanos; ALPD Asociación Latinoamericana de Periodistas para el Desarrollo.

También en esta red el CEAS tuvo un predominio importante (11 lazos) pero compartido con las embajadas extranjeras en Argentina (7 lazos). La relación entre ambos nodos era importantísima para conseguir pasajes y visas en otros países que fueran más seguro que la Argentina. En la red se encontraron 12 cliques superiores a tres nodos ${ }^{60}$. En ellos, cuatro estaban formados por la participación simultánea de

60 Cliques encontrados en la Red de Emigración:

embajadas extranjeras en Argentina; CEAS; exiliados con aval; exiliados sin aval; CRPC

embajadas extranjeras en Argentina; CEAS; CRPC; ACNUR (Buenos Aires)

embajadas extranjeras en Argentina; CEAS; CRPC; CMI

embajadas extranjeras en Argentina; CEAS; ACNUR (Buenos Aires); DNM

exiliados en otros países; CEAS; exiliados con aval; exiliados sin aval

exiliados en otros países; CEAS; exiliados con aval; Al

CEAS; ACNUR (Buenos Aires); ACNUR (Santiago de Chile)

CEAS; ACNUR (Buenos Aires); CAREF; DNM

CEAS; ACNUR (Buenos Aires); CAREF; Al

familiares en Chile; exiliados con aval; exiliados sin aval

exiliados en otros países; exiliados con aval; Al; UPACH; APV; ALPD

exiliados con aval 
las embajadas extranjeras en Argentina y el CEAS. Éste último aparecía en 9 de las ocho camarillas. Debe recordarse que el recorte de toda red responde a su necesidad de análisis. En este caso sólo aparecen los nodos que estaban en terceros países que están en los archivos del CEAS y en el periodo tomado para este artículo (1973-1976). Es decir que es un recorte dentro de la gran solidaridad internacional que recibió el caso chileno a nivel internacional. Por esta razón no aparecen otras organizaciones que serían parte de la red si se tomase la totalidad del periodo del gobierno militar chileno (1973-1989) o si se utilizaran otras fuentes primarias $^{61}$.

A continuación veremos como se cristalizaron estas redes para ayudar a reemigrar a dos refugiados: Renato y Emilio. El primero era un periodista chileno que se encontraba refugiado en Mendoza. Temiendo por su vida, otras organizaciones de periodistas gestionaron su arribo a Europa. Una de ellas fue la UPACH (Unión de Periodistas Antifacistas Chilenos), con sede en Venezuela, que envió una carta a Anmesty Internacional pidiendo la salida de Argentina de Renato por su seguridad. Pedido similar hicieron la Agrupación de Periodistas Venezolanos y la Asociación Latinoamericana de Periodistas para el Desarrollo, con sede en Colombia. El 6 de julio de 1976 Anmesty Internacional le contestó a UPACH, que luego del golpe militar del 24 de marzo de 1976 en Argentina intentará ayudarlo a salir del país. Además Petra Bherens de Anmesty Internacional, le escribió a Renato pidiéndole documentación para tramitarle la visa a través de CAREF de Buenos Aires ${ }^{62}$. Todas ellas eran organizaciones que colaboraron también en la sensibilización de la opinión pública internacional sobre el grado de represión en Chile y la necesidad de redemocratizarla. De modo que en torno a Renato se manifestó una fuerte red, que si bien estaba fuera del territorio nacional de Chile, era parte del escenario político chileno en tanto que impactaban o querían impactar en el gobierno del General A. Pinochet.

Otra red similar se entabló entorno a Emilio, un exiliado político chileno que fue detenido en noviembre de 1975 en la Penitenciaría Provincial de Mendoza. El 28 de setiembre de 1976 fue trasladado a la cárcel de Seguridad de la Ciudad de La Plata, donde se encontraba muy enfermo. Desde 1975 tenía visa para Suecia pero no

exiliados sin aval COMACHI

61 Entre otros organismos solidarios a la persecución política de chilenos puede mencionarse: CLACSO; el Parti Québécois de Canadá; el Instituto por el Nuevo Chile en Holanda; el Chile Democrático; la Asociación Cultural Chileno Danesa; el Bureau de la Resistencia; SIDA; Consejo Nórdico; Fondo Latinoamericano de Refugiados; Chile Committee for Human Rights; el Comité Antifascista y la actitud de los Gobiernos de Argelia, Suecia y los países de Europa del Este.

62 Carta del refugiado al CEAS, Mendoza, S/F y carta a ACNUR de CEAS, Mendoza, 28/12/76; legajo 300783. Archivo CEAS, Mendoza. 
podía salir. Parte de su familia que ya se encontraban en ese país, junto al grupo 33 del Swedish Section of Amnesty International, recolectaron 115 firmas pidiendo su liberación ${ }^{63}$. También esa organización le escribió al CEAS pidiéndole que hiciese todo lo posible para acelerar la salida de Emilio ${ }^{64}$. El CEAS les contestó que haría todo lo posible por liberarlo pero que, sabiendo que esto sería duro de aceptar para sus familiares en Suecia, no tenían medio de lograrlo sin una voluntad presidencial. Una situación similar vivían alrededor de 5.000 presos políticos en Argentina. Un abogado de ACNUR lo visitó a la cárcel para informar la situación al CEAS y a Suecia. Sobre Emilio había una acusación y las autoridades conocían la existencia de la visa y que parte de su familia estaba en Suecia. La respuesta del CEAS fue que juntar firmas para ser enviadas a la Argentina podía ser contraproducente y generar un endurecimiento aún mayor hacia el preso. La esposa vivía en Mendoza y el CEAS aconsejaba a la institución sueca que le enviaran medicamentos para que ella se los diera a Emilio ${ }^{65}$.

En Mendoza, el CEAS ofreció una importante red de contención que brindó asistencia y contactó a los refugiados entre sí. Otra red fue el Comité ArgentinoChileno (Com.A.Chi) que concentró a chilenos y argentinos identificados con la evolución socialista chilena, que querían denunciar los atropellos del gobierno militar chileno. Nucleaba a organizaciones sindicales, estudiantiles, partidos políticos (los más numerosos eran los partidarios de la Juventud Peronista y de la Izquierda revolucionaria), uniones vecinales, entidades culturales, donde manifestaban su solidaridad con el pueblo chileno. Esta agrupación era dirigida por Oscar Alende, en Buenos Aires. Luego se extendió por todo el país era un comité de solidaridad con el pueblo de Chile. Realizaron diversos actos en la Plaza Chile, en la ciudad de Mendoza, en homenaje a Salvador Allende y en repudio al General Pinochet ${ }^{51}$. Uno de los miembros era Miguel, un dirigente estudiantil y obrero chileno. Miguel trabajó en una empresa en el área social del Gobierno de Chile, que había sido estatizada por Allende y que era dirigida por el sindicato. El 12 de setiembre de 1973 fue detenido hasta marzo del año siguiente. Una vez en libertad siguió militando, con otros escribía en las calles Allende vive y volvió a caer detenido, fue torturado y amenazado de muerte. La agrupación política a la que

63 Nota de Petitorio, Gotemburg, diciembre de 1976, Bibliorato Correspondencia 1976, archivo CEAS.

64 Carta de Ingrid Åkerblom a ACNUR Mendoza, 17/12/76, Suecia. Bibliorato Correspondencia 1976, archivo CEAS.

65 Carta del CEAS a Swedish Section of Amnesty International, Mendoza, 31/12/76, Suecia. Bibliorato Correspondencia 1976, archivo CEAS.

51 Entrevistas Realizadas a Miguel Ángel Molina, Presidente del Centro de Residentes Chilenos de Mendoza, y Víctor Carabajal participante del mismo centro, en Mendoza, Agosto de 1999. 
pertenecía decidió que debía salir del país ya que habían detenido a su hermano. Llegó a Mendoza el 24 de octubre de 1974. Venía de tránsito a Europa pero se quedó porque creyó que el Gobierno de Pinochet no iba a durar tanto. "y me fui quedando y esta pesadilla duró 15 años" ${ }^{66}$. Miguel llegó a Mendoza con 17 años, vendía helados y su compañera 15 años y trabajaba como empleada doméstica cama adentro y niñera. Estaba embarazada de dos meses cuando llegaron de Chile, pero no lo sabían. En el COMACHI, Miguel trabajó apoyando a los exiliados desde 1974 hasta 1976. Durante el denominado Proceso de Reorganización Nacional (1976-1983), todo ese grupo de exiliados dejó de movilizarse. “Todos nos 'sumergimos', como decíamos en política, nos dedicamos a trabajar para poder vivir". Recién después de 1983 se reunieron y comenzaron a trabajar en el Chile Democrático.

\section{Conclusiones}

La visualización de la red que permitió la salida de Chile de perseguidos políticos y su asistencia en Mendoza es un logro importante para la historia local. Parte de la sociedad civil vio la llegada de chilenos como una invasión y la llamaron "migración aluvional". Desde esa perspectiva, Mendoza aparecía como un escenario de los acontecimientos, y como tal, era pasiva ante ese proceso. Por el contrario, la reconstrucción de esta red argentino-chilena presenta a los actores sociales mendocinos como promotores de la inmigración de chilenos hacia Mendoza.

Otro logro de este trabajo es la distinción de los nodos y las relaciones entre ellos, como una superposición de tres redes que buscaban distintos objetivos, en la ayuda solidaria hacia los perseguidos. Esto explica el mayor o menor compromiso de los nodos según el objetivo de su participación en la red. Las tres redes (la de presentación de exiliados ante organizaciones mendocinas, la de asistencia económica durante su estadía en Mendoza y la de reemigración a otros lugares más seguros) actuaban simultáneamente.

Desde una perspectiva individual, pueden analizarse las diferentes trayectorias de los exiliados a través de las tres redes: Algunos llegaban con un aval de una organización otros no; ya en Mendoza fueron asistidos de diferentes modos y posteriormente la mayoría reemigró a otros país o volvieron a Chile. En las trayectorias pueden encontrarse a exiliados de "primera clase" y otros más populares. Los primeros eran dirigentes políticos reconocidos, llegaban en avión financiado por alguna organización chilena. Traían más de una carta de aval y eran

66 Entrevista a Miguel Angel Molina, 14/2/01, Mendoza. 
rápidamente aceptados por el CEAS como refugiados políticos. Estaban en Mendoza poco tiempo, en tanto otras organizaciones en terceros países le tramitaban su visa. Era un paso rápido por Mendoza. A mediados de 1975, casi la totalidad de este grupo ya había reemigrado. Los otros exiliados eran menos reconocidos políticamente, algunos eran perseguidos sólo por haber pertenecido a la Unidad Popular. Algunos trajeron cartas de presentación e inclusive llegaron en avión, pero ante el CEAS les era más difícil demostrar su compromiso político con el gobierno de Salvador Allende. Nadie intercedía por ellos en el extranjero por lo que permanecieron más tiempo en Mendoza. Muchos de ellos fueron perseguidos por la dictadura argentina que los vio como potenciales subversivos.

Desde una perspectiva holística, las tres redes eran simultáneas temporal y espacialmente. Algunos exiliados llegaban el mismo día en que otros reemigraban por que eran asediados en Mendoza por personas extrañas. Esto hizo que las tres redes funcionasen durante todo el recorte temporal seleccionado. En cuanto a lo geográfico la participación de los mismos nodos en más de una red hizo que actuaran en forma yuxtapuestas. Sin embargo existen algunos matices. En la red de presentación interactuaron el $78 \%$ de los nodos localizados en Chile. Esto es porque esta red movilizó más recursos desde Chile hacia Mendoza y principalmente un tipo de recurso: Capital Social por medio de las cartas de aval, los llamados telefónicos y la organización de la acogida en Mendoza por el CEAS. En las otras redes los nodos chilenos tendrán menor participación, 21 y 14 por ciento en las redes de Asistencia y Reemigración, respectivamente. En la red de asistencia el centro de gravedad estuvo al otro lado de la cordillera de Los Andes, ya que comprometió al 77\% de los nodos mendocinos. Esto le costará, luego de 1976, la persecución de los dirigentes de las organizaciones: Dos bombas estallaron en el CEAS, varios de sus miembros debieron exiliarse y uno de ellos, Mauricio López, es un desaparecido. Finalmente, en la red de emigración adquirieron más peso los lazos que unían a los nodos que no estaban ni en Mendoza ni en Chile. Allí participaron el $100 \%$ de los nodos ubicados en otros países y el $80 \%$ de los que no se encontraban en Mendoza. Esto se debe a que al ser una ciudad fronteriza con Chile era conflictiva y varios refugiados denunciaron la presencia de grupos paramilitares chilenos que secuestraban exiliados para llevarlos a su país. El siguiente cuadro compara algunos aspectos de las tres redes. 


\begin{tabular}{|l|l|l|l|l|c|c|}
\hline \multirow{2}{*}{$\begin{array}{c}\text { Tipo de red } \\
\text { según objetivo } \\
\text { del intercambio }\end{array}$} & \multicolumn{1}{|c|}{ Chile } & \multicolumn{1}{|c|}{ Mendoza } & $\begin{array}{c}\text { Resto de } \\
\text { Argentina }\end{array}$ & Otros países & $\begin{array}{c}\text { Total de } \\
\text { nodos } \\
\text { por red }\end{array}$ & densidad \\
\cline { 2 - 6 } & $11(78 \%)$ & $7(54 \%)$ & $1(20 \%)$ & - & 19 & $21,64 \%$ \\
\hline Presentación & $3(21 \%)$ & $10(77 \%)$ & $2(40 \%)$ & $2(33 \%)$ & 17 & $18,38 \%$ \\
\hline Asistencia & $2(14 \%)$ & $6(46 \%)$ & $4(80 \%)$ & $6(100 \%)$ & 18 & $32,68 \%$ \\
\hline $\begin{array}{l}\text { Reemigración } \\
\text { Total de nodos de }\end{array}$ & $14(100 \%)$ & $13(100 \%)$ & $5(100 \%)$ & $6(100 \%)$ & $38(100 \%)$ & - \\
\hline
\end{tabular}

Cuadro 6. Comparación de Tamaño y densidad de las tres redes.

Nota: celdas sombreadas en las que aparece más del $75 \%$ de los nodos de esa localidad en la red. Fuente: Elaboración propia

Las tres redes tenían tamaños similares pero la densidad de la red de reemigración es bastante mayos que las otras dos. El análisis individual refuerza aspectos diacrónicos de las redes (Ilegada, permanencia y partida de Mendoza) y el holístico el espacial (Chile - Mendoza - otros lugares más seguros). Ambos análisis ayudan a entender la solidaridad entre regiones limítrofes en situaciones de crisis. La situación fue caótica también para los nodos mendocinos. Algunos recuerdan al templo metodista repleto de gente durmiendo en cada rincón, separados por biombos en altísimas condiciones de hacinamiento ${ }^{67}$. Si en un primer momento los chilenos llegaron en estado de shock, los que los asistían tampoco sabían muy bien que hacer. Es allí cuando el financiamiento y la orientación proveniente de ACNUR y del Consejo Mundial de Iglesias fueron decisivos. Ambas instituciones tenían experiencia en este tipo de tareas y transfirieron a los mendocinos sus conocimientos. Su ayuda otorgó continuidad y cierta inmunidad a la asistencia de los chilenos. Muchas tareas hubieran sido imposibles sin su apoyo económico. La vida cotidiana de Mendoza se transformó y se enriqueció con nuevos patrones y valores culturales, que le dieron a la idiosincrasia mendocina cierta estampa distintiva. También repercutió en la política local según la influencia de los objetivos de estos nuevos grupos incorporados y del desarrollo de diversas redes de solidaridad.

Finalmente, estas redes muestran la reactualización del Pacto Fundacional de Mendoza. Los aspectos acá analizados sirven de ilustración de como las redes mendocino-santiaguinas, han actuado en ambos momentos de la historia chilena. Los sectores perdedores de la arena política buscaron aliados con iguales tendencias ideológicas en este lado de la cordillera. Hechos similares ocurrieron en 1814 y también durante la presidencia de Salvador Allende, cuando sectores de la derecha chilena buscaron el apoyo de sus pares en Mendoza.

67 Entrevista a Ana María Van Leeuwen, Mendoza, 17/2/06. 


\section{Bibliografía}

Borgatti, S.P., Everett, M.G. and Freeman, L.C. 2002. Ucinet for Windows: Software for Social Network Analysis. Harvard, MA: Analytic Technologies.

Bozzano, Horacio (2000). Territorio reales, territorios pensados, territorios posibles, Buenos Aires: Espacio

Bustelo, Gastón (2001). “Impacto de la dictadura pinochetista en Mendoza (19731988)", Revista de Estudios Trasandinos №5, Santiago de Chile, pp.355-356.

Caballero, Estrella (2005). “Pluralidad teórica, metodológica y técnica en el abordaje de las redes sociales: hacia la "hibridación" disciplinaria", REDES, Vol.9 № 1, http: //revista-redes. rediris.es

Carrasco Norambuena, Carmen (1998). Araucanías y pampas. Un mundo fronterizo en América del Sur, Temuco: ediciones U. De la frontera.

Codina, Iverna (1993). Detrás del grito. Mendoza: Ediciones Culturales Mendoza.

Dabas, Elina (1998). Red de redes. Las prácticas de la intervención en redes sociales. Buenos Aires: Paidós (2ª reimpresión).

Dabas, Elina y Najmanovich (comp.) (1995). Redes. El lenguaje de los vínculos. Hacia la reconstrucción y el fortalecimiento de la sociedad civil. Buenos Aires: Paidós.

Fernández Rojas, Jorge (2003). "Felipe Esteve. El otro fundador de Mendoza", Rumbos, $N^{\circ} 14$, Mendoza, 30/11/03, p.II

Ferrand, A. (2002). "Las comunidades locales como estructuras meso", Revista REDES. Vol.3, № 4, http://revista-redes.rediris.es

Hanneman, Robert y Mark Riddle (2005). Introduction to social network methods. Riverside, CA: University of California, Riverside, http://faculty.ucr.edu/ hanneman Heras, Eduardo; Guillot, Daniel; Galvez, Rodolfo (1978). Migración Tradicional y Migración de Crisis. Una década de afluencias bolivianas y chilenas a Argentina y la región cuyana (1965-1975). Mendoza: PISPAL.

Hudson, Damián (1931). Recuerdos históricos sobre la provincia de Cuyo, Mendoza: Editorial Revista mendocina de ciencias.

Maya Jariego, Isidro (2004). “La formación de comunidades de inmigrantes: desplazamiento en cadena y contexto de recepción", Revista Araucaria. Año 5, № 12, http://www.institucional.us.es/araucaria. 
Maza, Juan I sidro (1991). Malargüe, Mendoza: Editorial de la Facultad de Filosofía y Letras- Universidad Nacional de Cuyo.

Molina, José Luis (2001). El análisis de redes sociales. Una introducción. Barcelona: Edicions Bellaterra.

Orellana, Patricio (1981). El exilio chileno, Falmer: Institute of Development Studies-University of Sussex

Plata Caviedes, Juan (2006). "Reconstrucción de las redes sociales: el caso de las FARC, el ELN y las ACCU-AUC", Redes, Vol.10. http://revista-redes.rediris.es Pizarro, Narciso (2004). “Un nuevo enfoque sobre la equivalencia estructural: lugares y redes de lugares como herramientas para la teoría sociológica" Revista REDES, Vol. 5, № 2, htpp://revista-redes.rediris.es

Potrykowski, Marek y Taylor, Zbigniew (1984). Geografía del transporte. Barcelona: Ariel.

Scher, Ofelia Beatriz (1997). “Inmigración limítrofe a la República Argentina una aproximación al caso chileno 1950/1990" Revista de Estudios Trasandinos, №1, Santiago de Chile.

S/A (1979). Anuario Estadístico 1977 y 1978. Mendoza: Dirección de Estadísticas y Censos.

World Council of Churches (1987). "Refugiados de América del Sur", RefugeesRefugies-Flüchtlinge-Refugiados, N86, Geneva. 


\section{Fuentes de archivo CEAS}

"Proyecto de asistencia salud mental. Caso M", 3/4/86, Borrador, Cartas Notas enviadas del año 1982 a 1987.

"Rehabilitación psicosocial de refugiados en Argentina. Caso Srta A", 4/4/86, Cartas Notas enviadas del año 1982 a 1987.

"Solicitud de Ayuda ACNUR", 25/11/91, en Carpeta Repatriaciones 1991.

"Solicitud de Ayuda ACNUR", 31/10/91, en Carpeta Repatriaciones 1991.

Carta de la Iglesia Evangélica Alemana de Valparaíso al CEAS, 3/1/75 y 26/2/75, legajo 30-0768.

Carta de la Segunda I glesia Metodista al CEAS, 9/1/75, legajo 30-0804.

Carta de presentación Universidad Católica de Chile, Santiago, S/F y carta de presentación Colegio San Ignacio, Santiago, 10/12/74, legajo 30-779.

Carta de la COAR al CEAS, 3/2/75, legajos 30-0828 y 30-0829.

Carta de la COAR al Ejército de Salvación-Mendoza, Santiago, Ag-1975 leg.30-1186

Carta del Consejo de Delegados de Refugiados Políticos en Mendoza a todas las embajadas en Argentina, 27/8/78, Bibliorato Correspondencia 1978: Letra D.

Carta del refugiado a ACNUR, 21/1/77, legajo 30-759.

Carta del refugiado al CEAS, Mendoza 21/11/78 legajo 30-780.

Carta de José María Llorens al Comité Ecuménico, Barrio San Martín, 4/11/75, Legajos 301275 y $30-1273$.

Carta del refugiado 30-704 presentando al que luego será el refugiado 30-1244, Mendoza, 10/10/75. Legajo 30-1244.

Certificado de situación de presidiario firmado por el coronel Jorge Espinoza Ulloa, santiago, 18/6/75. Legajo 30-1244.

Declaración de exiliada en "Solicitud de Ayuda ACNUR", 31/10/91, Carpeta Repatriaciones 1991.

Declaración de exiliado "Solicitud de Ayuda ACNUR", 26/2/91, Carpeta Repatriaciones 1991.

Declaración de exiliado en "Solicitud de Ayuda al ACNUR", 14/8/89, Carpeta Repatriaciones (88-89), Letra KL.

Declaración de exiliado en "Solicitud de Ayuda al ACNUR", 16/11/89, Carpeta Repatriaciones (88-89), Letra GH.

Declaración de exiliado en "Solicitud de Ayuda al ACNUR", 19/1/90, Carpeta Repatriaciones (88-89), Letra C.

Declaración de exiliado en "Solicitud de Ayuda al ACNUR", 21/11/91, Carpeta Repatriaciones 1991.

Declaración de exiliado en "Solicitud de Ayuda al ACNUR", 23/5/91, Carpeta Repatriaciones 1991, archivo CEAS, Mendoza

Declaración de refugiado (manuscrito, sin fecha), carpeta "Repatriaciones voluntarias (1988-1989)", letra M. Archivo CEAS, Mendoza.

Entrevista a 6 ex miembros del CEAS, 2004-2006, Mendoza.

Entrevista a 10 vecinos del barrio Cristo Salvador, 13/03/85, por las Asistentes Sociales de la FEC, Carpeta Cristo Salvador, archivo CEAS, Mendoza. 
Entrevista a Loreto, ex militante del MIR, Santiago de Chile, 9/01/07

Entrevista a miembro de la Comisión Chilena de Derechos Humanos, Santiago de Chile, enero 2002.

Entrevista a 2 miembros del Centro de Residentes Chilenos, Mendoza, 1999 y 2001.

Entrevista a Pablo, ex militante del ERP, Mendoza, 2/8/06.

Informe social CCAI, marzo de 1980, Letra A, Carpeta Informe social, archivo CEAS, Mendoza.

CAREF (S/F) "Un fenómeno angustiante", Bibliorato correspondencia enviada y recibida 1980.

Legajos de 408 refugiados políticos chilenos en Mendoza citados en el artículo:

01-0245; 01-0296; 01-0347; 280; 30-0001; 30-0002; 30-0003; 30-0004; 30-0005; 300006 ; 30-0007; 30-0008; 30-0009; 30-0010; 30-0011; 30-0012; 30-0013; 30-0014; 30$0015 ; 30-0016 ; 30-0017 ; 30-0018 ; 30-0019 ; 30-0020 ; 30-0021 ; 30-0022 ; 30-0023 ; 30-$ 0024; 30-0025; 30-0026; 30-0027; 30-0028; 30-0029; 30-0030; 30-0031; 30-0032; 300033 ; 30-0034; 30-0035; 30-0036; 30-0037; 30-0038; 30-0039; 30-0040; 30-0041; 30$0042 ; 30-0043 ; 30-0044 ; 30-0045 ; 30-0046 ; 30-0047 ; 30-0048 ; 30-0049 ; 30-0050 ; 30-$ 0051; 30-0052; 30-0053; 30-0054; 30-0055; 30-0056; 30-0057; 30-0058; 30-0059; 300060 ; 30-0061; 30-0062; 30-0063; 30-0064; 30-0065; 30-0065; 30-0066; 30-0067; 30$0068 ; 30-0070 ; 30-0071 ; 30-0072 ; 30-0073 ; 30-0074 ; 30-0075 ; 30-0076 ; 30-0077 ; 30-$ $0078 ; 30-0079 ; 30-0080 ; 30-0081 ; 30-0082 ; 30-0083 ; 30-0084 ; 30-0085 ; 30-0086 ; 30-$ 0087; 30-0088; 30-0089; 30-0090; 30-0091; 30-0092; 30-0093; 30-0094; 30-0095; 300096; 30-0097; 30-0098; 30-0099; 30-0100; 30-0101; 30-0102; 30-0103; 30-0104; 300105; 30-0106; 30-0107; 30-0108; 30-0108; 30-0109; 30-0110; 30-0111; 30-0112; 300113 ; 30-0114; 30-0115; 30-0116; 30-0117; 30-0118; 30-0119; 30-0120; 30-0121; 300122; 30-0123 o 205.; 30-0124; 30-0125; 30-0126; 30-0127; 30-0128; 30-0129; 30-0130; $30-0131 ; 30-0131 ; 30-0132 ; 30-0133 ; 30-0134 ; 30-0135 ; 30-0136 ; 30-0137 ; 30-0138$; 30-0139; 30-0140; 30-0141; 30-0142; 30-0143; 30-0144; 30-0145; 30-0146; 30-0147; 30-0148; 30-0149; 30-0150; 30-0151; 30-0152; 30-0153; 30-0154; 30-0155; 30-0156; 30-0157; 30-0158; 30-0159; 30-0160; 30-0161; 30-0162; 30-0163; 30-0164; 30-0165; 30-0166; 30-0167; 30-0168; 30-0169; 30-0170; 30-0171; 30-0172; 30-0173; 30-0174; $30-0175 ; 30-0176 ; 30-0177 ; 30-0178 ; 30-0179 ; 30-0180 ; 30-0181 ; 30-0182 ; 30-0183$; 30-0184; 30-0185; 30-0186; 30-0187; 30-0188; 30-0189; 30-0190; 30-0191; 30-0191; 30-0192; 30-0193; 30-0194; 30-0195; 30-0196; 30-0197; 30-0198; 30-0199; 30-0200; $30-0201 ; 30-0202 ; 30-0203 ; 30-0204 ; 30-0205 ; 30-0206 ; 30-0207 ; 30-0208 ; 30-0209$; 30-0210; 30-0211; 30-0212; 30-0213; 30-0214; 30-0215; 30-0216; 30-0217; 30-0218; 30-0219; 30-0220; 30-0221; 30-0222; 30-0223; 30-0224; 30-0225; 30-0226; 30-0227; 30-0228; 30-0229; 30-0230; 30-0231; 30-0232; 30-0233; 30-0234; 30-0235; 30-0236; 30-0237; 30-0238; 30-0239; 30-0240; 30-0241; 30-0242; 30-0243; 30-0244; 30-0245; 30-0246; 30-0246 bis; 30-0247; 30-0248; 30-0249; 30-0250; 30-0251; 30-0252; 30-0253; $30-0254 ; 30-0255 ; 30-0256 ; 30-0256 ; 30-0257 ; 30-0258 ; 30-0259 ; 30-0260 ; 30-0261$; 30-0262; 30-0263; 30-0264; 30-0265; 30-0266; 30-0267; 30-0268; 30-0269; 30-0270; $30-0271 ; 30-0272 ; 30-0273 ; 30-0274 ; 30-0275 ; 30-0276 ; 30-0277 ; 30-0278 ; 30-0279$; $30-0280 ; 30-0281 ; 30-0282 ; 30-0283 ; 30-0284 ; 30-0285 ; 30-0286 ; 30-0287 ; 30-0288$; 30-0289; 30-0290; 30-0291; 30-0292; 30-0293; 30-0294; 30-0295; 30-0296; 30-0297; 30-0298; 30-0299; 30-0300; 30-0301; 30-0302; 30-0303; 30-0304; 30-0305; 30-0306; 30-0307; 30-0308; 30-0309; 30-0309; 30-0310; 30-0311; 30-0312; 30-0313; 30-0314; 30-0314; 30-0315; 30-0315; 30-0316; 30-0316; 30-0317; 30-0318; 30-0319; 30-0320; 30-0321; 30-0322; 30-0323; 30-0324; 30-0325; 30-0326; 30-0326; 30-0327; 30-0328; 30-0329; 30-0330; 30-0331; 30-0332; 30-0333; 30-0333; 30-0334; 30-0335; 30-0336; 30-0337; 30-0337; 30-0338; 30-0339; 30-0340; 30-0341; 30-0342; 30-0343; 30-0344; 30-0345; 30-0346; 30-0347; 30-0348; 30-0349; 30-0350; 30-0351; 30-0352; 30-0353; $30-0354 ; 30-0354 / 1 ; 30-0355 ; 30-0356 ; 30-0357 ; 30-0358 ; 30-0359 ; 30-0359 ; 30-0360$; $30-0361 ; 30-0362 ; 30-0363 ; 30-0364 ; 30-0365 ; 30-0366 ; 30-0367 ; 30-0368 ; 30-0369$; 30-0370; 30-0371; 30-0372; 30-0373; 30-0374; 30-0493; 30-0814; 30-0835; 30-0896; 30-0915; 30-0949; 30-0952; 30-1016; 30-1321; 30-1341; 30-1364; 30-1377; 30-1388; 30-1397; 30-2312; 30-2332. 